\title{
Pollen Morphology and Variability of Abies alba Mill. Genotypes from South-Western Poland
}

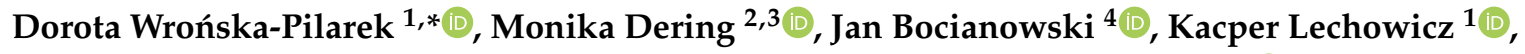 \\ Wojciech Kowalkowski ${ }^{2}$, Władysław Barzdajn ${ }^{2}$ and Maria Hauke-Kowalska ${ }^{2}$ D \\ 1 Department of Forest Botany, Poznań University of Life Sciences, Wojska Polskiego 71 d, \\ 60-625 Poznań, Poland; kacper.lechowicz@up.poznan.pl \\ 2 Department of Silviculture, Poznań University of Life Sciences, Wojska Polskiego 71 a, \\ 60-625 Poznań, Poland; monika.dering@up.poznan.pl (M.D.); wojciech.kowalkowski@up.poznan.pl (W.K.); \\ barzdajn@up.poznan.pl (W.B.); maria.hauke@up.poznan.pl (M.H.-K.) \\ 3 Institute of Dendrology, Polish Academy of Sciences, Parkowa 5, 62-035 Kórnik, Poland \\ 4 Department of Mathematical and Statistical Methods, Poznań University of Life Sciences, Wojska Polskiego 28, \\ 60-637 Poznań, Poland; jan.bocianowski@up.poznan.pl \\ * Correspondence: dorota.wronska-pilarek@up.poznan.pl
}

Received: 2 September 2020; Accepted: 19 October 2020; Published: 22 October 2020

\begin{abstract}
The objective of this study was to investigate pollen morphology and ranges of intraspecific variability of Abies alba Mill. Pollen grains were collected from nine clonal seed orchards of A. alba in the Sudety Mountains, (South-Western Poland). At each seed orchard, 4-6 grafts were selected. Each individual (graft) was represented by 30 pollen grains and 1440 pollen grains were measured totally. Eight quantitative and four qualitative features of pollen grains were analysed. The diagnostic features of pollen grains for the studied species were: Exine surface of pollen corpus (cappa and leptoma) and sacci, the length of the polar axis $(\mathrm{P})$, pollen shape $(\mathrm{P} / \mathrm{E}$ ratio), and a new trait-saccus shape (A/B ratio - saccus width (A) to his length (B)). Pollen features made possible to differentiate seven individual genotypes (samples). To our knowledge, this is the first time that the intraspecific and interindividual variability of pollen grains of $A$. alba were investigated. The most different were the pollen grains from samples-genotypes 13 (Bystrzyca Kłodzka) and 18 (Jugów), and also (although to a lesser extent) genotypes-11 (Kamienna Góra), 30, 31 (Jugów), and 44 (Szklarska Poręba). No significant relationships were observed between the pollen grain traits and the geographical location of the collection sites.
\end{abstract}

Keywords: pollen morphology; intraspecific variability; DNA variability; genotype; abies; abies alba

\section{Introduction}

Biologically, the production of pollen is a crucial stage of sexual reproduction in plants, involving the transfer of parental genes to offspring generations. However, from a forestry perspective pollen production is the process that affects the amount and frequency of seed crops in economically important trees. By simplifying reproduction to the perspective of pollen donors only, the seed crop to a large extent depends on the pollen amount, its quality, and efficiency of the dispersal. In wind-pollinated plants, a majority being the European forest tree species, stochasticity of the pollination process evolutionarily has required the production of a large amount of pollen [1]. Pollen dispersal distance affects pollination rate and thus seed crop is largely the function of intrinsic pollen grain characteristics (size, weight, and morphology) that governs the physics of dispersion. The size of pollen production, the dispersal distance, and pollen viability are all modified under environmental influence [2], which attains a special context under the observed climate transformation. 
Among several species from the genus Abies present in Europe, A. alba Mill. possesses the widest occurrence spanning from the mountainous areas in Southern Europe (Spain) up to the lowlands of Central Europe (Poland). It is an ecologically and economically important forest tree species and one of the most productive among native European conifers [3]. However, due to the peculiar forest management requirements of the species that reflect its late-successional character, other conifers have been favoured over silver fir in the forestry since the 19th century [4]. In many areas of Central Europe that are suitable for silver fir, the species has been replaced by Picea abies (L.) Karst. or Fagus sylvatica L. to cover the great demand for wood at certain times [5,6]. However, both of the above-mentioned species are more drought sensitive in comparison to silver fir $[4,7,8]$. Considering the results that suggest a great potential of silver fir in view of the expected climate changes, it seems to be the species of choice for European forestry, especially in the context of the dramatic conditions of the Norway spruce stands to be decimated with bark beetle [4] and there is a retreating trend predicted for Scots pine [9]. Currently, the share of silver fir in Poland is 3.2\% of forest areas [10]. Populations are mostly distributed in the mountainous areas, while the lowland range is highly fragmented and low-density stands prevail [11].

Mast years in silver fir occur every three to five years but these crops often display a high proportion of empty seeds [12], which may be related to its lower dispersal ability of pollen. It is because, A. alba produces very heavy pollen of ca. $251.1 \times 10^{-6} \mathrm{~g}$ per 1000 grains and a sedimentation velocity of ca. $0.12 \mathrm{~m} \mathrm{~s}^{-1}$ [13]. These features may likely reduce the potential of pollen migration and affect successful pollination and finally, seed production, especially in the complex mountainous landscape or fragmented populations. Experimental data obtained from the parentage analysis based on the genetic markers indicate that pollen movement in old-grown silver fir stands varies substantially. The pollen can be dispersed on average over a distance of ca. $100 \mathrm{~m}$ in populations from the northern range margins (Poland) [14,15]. However, a very local dispersion was noted reaching only $11 \mathrm{~m}$ on average in old populations from the southern range margin (France) [14]. In the years with low flower production or in isolated, fragmented, and low-density stands, self-fertilization may be common (ca. 95\%) [16]. It likely reflects the high inbreeding depression, typical for many conifers [17].

The knowledge of the morphological structure of Abies Mill. pollen grains is incomplete due to the small amount of research on this subject, especially in Europe. Researchers usually limit their analyses to individual and/or the most important pollen grain features, mainly pollen size and shape, or exine ornamentation. As yet no other research on the intraspecific variability of $A$. alba pollen has been undertaken. Ting [18] studied the pollen morphology of the five Abies species (A. bracleafa (D. Don) Nutt., A. concolor (Gordon et Glend.) Lindl. ex Hildebr., A. grandis (Douglas ex D. Don) Lindl., A. magnifica Murr., and A. procera Rehder) from California. Gudeski [19] examined and compared pollen grains of $A$. alba from populations in Macedonia and of A. cephalonica Loudon from Parnis in Greece. Bagnell Jr. [20] showed that three species of Abies (A. amabilis Douglas ex J. Forbes, A. grandis, and A. lasiocarpa (Hook.) Nutt.) differ in the respect of the morphology of the impression mark. Dobrinov and Gagov [21] analysed the morphology, viability, and storage of pollen from four native populations of $A$. alba in Bulgaria. The "Pal dat" database, established by Halbritter [22-24], contains brief descriptions of pollen of A. cephalonica, A. concolor, and A. nordmanniana (Steven) Spach. Khan et al. [25] described two species from Pakistan-A. pindrow (Royle) Spach. and A. spectabilis (D. Don) Mirb. According to the palynological studies mentioned, species from the genus Abies produce heteropolar monads. Pollen grains are large or very large, bisaccate (rarely one or trisaccate) with the impression mark on the proximal face. They have one aperture, the leptoma. The exine surface is psilate with or without perforations, regulate, or verrucate [18-20,22-26].

The main aim of this study was to supplement knowledge concerning pollen morphology in A. alba, an important forest tree species in Europe. Particularly, we aimed at establishing the pollen morphology and variability of $A$. alba collected in nine provenance areas located in South-Western Poland. The aims of this study were to verify the usefulness of the previously described as well as the new quantitative and qualitative pollen features and to describe, for the first time, the intraspecific and 
inter-individual variability of pollen of the studied $A$. alba genotypes. The obtained results will be useful in future studies on the reproduction of $A$. alba and contribute to its restitution in Poland.

\section{Material and Methods}

\subsection{Sampling and Genotyping}

The analysis was conducted on 48 genotypes (samples) of $A$. alba that grow in 9 native localities of the studied species in the Sudetes Mountains located in South-Western Poland. The clonal seed orchards from which pollen was collected, were established for the 'Program of the silver fir Abies alba Mill. restitution in the Sudety Mountains' and the clone archive in the Karkonosze National Park. A list of the studied samples is shown in Table 1. As the pollen samples were taken from trees growing in the clonal seed orchards (Figure 1), there was a potential risk of errors in the labelling that would lead to the sampling of the same genotype, i.e., grafts within the same clone. To ensure that pollen analysis includes distinct individuals, genotyping with 6 nuclear microsatellite markers was done. Needle samples were taken from each individual tree subjected to pollen morphology analysis. Genomic DNA was extracted using the protocol of [27]. For the purpose of genotyping, a set of 6 nuclear microsatellites was used as follows: SFb5, SF333, SF1, SF239, SF78, and SFb4 [28,29]. Loci were amplified in a single PCR-multiplex reaction with the Qiagen Multiplex PCR Kit (Qiagen, Hilden, Germany) according to the manufacturer's instructions with ca. $20 \mathrm{ng}$ of genomic DNA. The thermal profile included an initial denaturation at $95^{\circ} \mathrm{C}$ for $15 \mathrm{~min}$., and 10 touchdown cycles as follows: $94{ }^{\circ} \mathrm{C}$ for $30 \mathrm{~s}, 60{ }^{\circ} \mathrm{C}$ for $30 \mathrm{~s}\left(-1{ }^{\circ} \mathrm{C}\right.$ per cycle), and $72{ }^{\circ} \mathrm{C}$ for $40 \mathrm{~s}$, and 30 more cycles as follows $94{ }^{\circ} \mathrm{C}$ for $30 \mathrm{~s}, 50{ }^{\circ} \mathrm{C}$ for $50 \mathrm{~s}, 72{ }^{\circ} \mathrm{C}$ for $40 \mathrm{~s}$, and a final extension of $7 \mathrm{~min}$ at $72{ }^{\circ} \mathrm{C}$. Analysis of the fluorescently labelled PCR products was done on an ABI PRISM 3130 genetic analyser with the GeneScan 500-LIZ size standard (Life Technologies, Bleiswijk, The Netherlands). Genotypes were scored using the GeneMapper v. 4.0. software package (Applied Biosystems, Foster City, CA, USA).

Table 1. List of localities of the studied Abies alba genotypes.

\begin{tabular}{|c|c|c|c|c|}
\hline $\begin{array}{l}\text { Sample } \\
\text { Numer }\end{array}$ & $\begin{array}{l}\text { Clone } \\
\text { Numer }\end{array}$ & Seed Orchard Location & Abbreviation & $\begin{array}{c}\text { Geographical } \\
\text { Coordinates (N/E) }\end{array}$ \\
\hline 1 & 40,077 & $\begin{array}{c}\text { Karkonosze National Park } \\
\text { Jagniątków }\end{array}$ & JAG-Jagniątków & $\begin{array}{l}50.82693 \\
15.63309\end{array}$ \\
\hline 2 & 4064 & $\begin{array}{c}\text { Bystrzyca Kłodzka Forest District } \\
\text { Pokrzywno }\end{array}$ & B-Bystrzyca & $\begin{array}{c}50.3742 \\
16.50961\end{array}$ \\
\hline 3 & 4144 & $\begin{array}{c}\text { Bystrzyca Kłodzka Forest District } \\
\text { Pokrzywno }\end{array}$ & B-Bystrzyca & $\begin{array}{c}50.3742 \\
16.50961\end{array}$ \\
\hline 4 & 20,011 & $\begin{array}{c}\text { Karkonosze National Park } \\
\text { Karpacz }\end{array}$ & K-Karpacz & $\begin{array}{l}50.76456 \\
15.68285\end{array}$ \\
\hline 5 & 10,041 & $\begin{array}{c}\text { Karkonosze National Park } \\
\text { Karpacz }\end{array}$ & K-Karpacz & $\begin{array}{l}50.76456 \\
15.68285\end{array}$ \\
\hline 6 & 40,019 & $\begin{array}{c}\text { Karkonosze National Park } \\
\text { Jagniątków }\end{array}$ & JAG-Jagniątków & $\begin{array}{l}50.82693 \\
15.63309\end{array}$ \\
\hline 7 & 40,036 & $\begin{array}{c}\text { Karkonosze National Park } \\
\text { Jagniątków }\end{array}$ & JAG-Jagniątków & $\begin{array}{l}50.82693 \\
15.63309\end{array}$ \\
\hline 8 & 40,056 & $\begin{array}{c}\text { Karkonosze National Park } \\
\text { Jagniątków }\end{array}$ & JAG-Jagniątków & $\begin{array}{l}50.82693 \\
15.63309\end{array}$ \\
\hline 9 & 87 & $\begin{array}{c}\text { Kamienna Góra Forest District } \\
\text { Ogorzelec }\end{array}$ & KG_Kamienna Góra & $\begin{array}{c}50.76653 \\
15.8967\end{array}$ \\
\hline 10 & 142 & $\begin{array}{c}\text { Kamienna Góra Forest District } \\
\text { Ogorzelec }\end{array}$ & KG_Kamienna Góra & $\begin{array}{c}50.76653 \\
15.8967\end{array}$ \\
\hline
\end{tabular}


Table 1. Cont

\begin{tabular}{|c|c|c|c|c|}
\hline $\begin{array}{l}\text { Sample } \\
\text { Numer }\end{array}$ & $\begin{array}{l}\text { Clone } \\
\text { Numer }\end{array}$ & Seed Orchard Location & Abbreviation & $\begin{array}{c}\text { Geographical } \\
\text { Coordinates (N/E) }\end{array}$ \\
\hline 11 & 127 & $\begin{array}{c}\text { Kamienna Góra Forest District } \\
\text { Ogorzelec }\end{array}$ & KG_-Kamienna Góra & $\begin{array}{c}50.76653 \\
15.8967\end{array}$ \\
\hline 12 & 24 & $\begin{array}{c}\text { Snieżka Forest District } \\
\text { Maciejowa }\end{array}$ & M-Maciejowa & $\begin{array}{l}50.91411 \\
15.82753\end{array}$ \\
\hline 13 & 4063 & $\begin{array}{c}\text { Bystrzyca Kłodzka Forest District } \\
\text { Pokrzywno }\end{array}$ & B-Bystrzyca & $\begin{array}{c}50.3742 \\
16.50961\end{array}$ \\
\hline 14 & 4002 & $\begin{array}{c}\text { Bystrzyca Kłodzka Forest District } \\
\text { Pokrzywno }\end{array}$ & B-Bystrzyca & $\begin{array}{c}50.3742 \\
16.50961\end{array}$ \\
\hline 15 & 60,046 & $\begin{array}{c}\text { Karkonosze National Park } \\
\text { Szklarska Poręba }\end{array}$ & SP_Szklarska Poręba & $\begin{array}{l}50.81837 \\
15.47205\end{array}$ \\
\hline 16 & 3021 & $\begin{array}{c}\text { Lądek Zdrój Forest District } \\
\text { Trzebieszowice }\end{array}$ & LZ_Lądek Zdrój & $\begin{array}{l}50.34253 \\
16.77332\end{array}$ \\
\hline 17 & 198 & $\begin{array}{c}\text { Śnieżka Forest District } \\
\text { Maciejowa }\end{array}$ & M-Maciejowa & $\begin{array}{l}50.91411 \\
15.82753\end{array}$ \\
\hline 18 & 5341 & $\begin{array}{l}\text { Jugów Forest District } \\
\text { Wojbórz }\end{array}$ & JUG—Jugów & $\begin{array}{c}50.5089 \\
16.63274\end{array}$ \\
\hline 19 & 5335 & $\begin{array}{c}\text { Jugów Forest District } \\
\text { Wojbórz }\end{array}$ & JUG—Jugów & $\begin{array}{l}50.5089 \\
16.63274\end{array}$ \\
\hline 20 & 12 & $\begin{array}{c}\text { Śnieżka Forest District } \\
\text { Maciejowa }\end{array}$ & M-Maciejowa & $\begin{array}{l}50.91411 \\
15.82753\end{array}$ \\
\hline 21 & 235 & $\begin{array}{l}\text { Śnieżka Forest District } \\
\text { Maciejowa }\end{array}$ & M-Maciejowa & $\begin{array}{l}50.91411 \\
15.82753\end{array}$ \\
\hline 22 & 6031 & $\begin{array}{l}\text { Zdroje Forest District } \\
\text { Duszniki }\end{array}$ & Z-Zdroje & $\begin{array}{l}50.40094 \\
16.39554\end{array}$ \\
\hline 23 & 6078 & $\begin{array}{l}\text { Zdroje Forest District } \\
\text { Duszniki }\end{array}$ & Z-Zdroje & $\begin{array}{l}50.40094 \\
16.39554\end{array}$ \\
\hline 24 & 60,017 & $\begin{array}{l}\text { Karkonosze National Park } \\
\text { Szklarska Poręba }\end{array}$ & SP-Szklarska Poręba & $\begin{array}{l}50.81837 \\
15.47205\end{array}$ \\
\hline 25 & 6074 & $\begin{array}{c}\text { Zdroje Forest District } \\
\text { Duszniki }\end{array}$ & Z-Zdroje & $\begin{array}{l}50.40094 \\
16.39554\end{array}$ \\
\hline 26 & 3014 & $\begin{array}{c}\text { Ladek Zdrój Forest District } \\
\text { Trzebieszowice }\end{array}$ & LZ—Lądek Zdrój & $\begin{array}{l}50.34253 \\
16.77332\end{array}$ \\
\hline 27 & 3158 & $\begin{array}{c}\text { Lądek Zdrój Forest District } \\
\text { Trzebieszowice }\end{array}$ & LZ_Lądek Zdrój & $\begin{array}{l}50.34253 \\
16.77332\end{array}$ \\
\hline 28 & 40,073 & $\begin{array}{c}\text { Karkonosze National Park } \\
\text { Jagniątków }\end{array}$ & JAG-Jagniątków & $\begin{array}{l}50.82693 \\
15.63309\end{array}$ \\
\hline 29 & 60,135 & $\begin{array}{l}\text { Karkonosze National Park } \\
\text { Szklarska Poręba }\end{array}$ & SP_Szklarska Poręba & $\begin{array}{l}50.81837 \\
15.47205\end{array}$ \\
\hline 30 & 5347 & $\begin{array}{c}\text { Jugów Forest District } \\
\text { Wojbórz }\end{array}$ & JUG—Jugów & $\begin{array}{c}50.5089 \\
16.63274\end{array}$ \\
\hline 31 & 5262 & $\begin{array}{c}\text { Jugów Forest District } \\
\text { Wojbórz }\end{array}$ & JUG—Jugów & $\begin{array}{c}50.5089 \\
16.63274\end{array}$ \\
\hline 32 & 10,038 & $\begin{array}{c}\text { Karkonosze National Park } \\
\text { Karpacz }\end{array}$ & K-Karkonosze & $\begin{array}{l}50.76456 \\
15.68285\end{array}$ \\
\hline 33 & 78 & $\begin{array}{c}\text { Śnieżka Forest District } \\
\text { Maciejowa }\end{array}$ & M-Maciejowa & $\begin{array}{l}50.91411 \\
15.82753\end{array}$ \\
\hline 34 & 60,002 & $\begin{array}{c}\text { Karkonosze National Park } \\
\text { Szklarska Poręba }\end{array}$ & SP_Szklarska Poręba & $\begin{array}{l}50.81837 \\
15.47205\end{array}$ \\
\hline 35 & 30,006 & $\begin{array}{c}\text { Karkonosze National Park } \\
\text { Karpacz }\end{array}$ & K-Karkonosze & $\begin{array}{l}50.76456 \\
15.68285\end{array}$ \\
\hline 36 & 20,019 & $\begin{array}{c}\text { Karkonosze National Park } \\
\text { Karpacz }\end{array}$ & K-Karkonosze & $\begin{array}{l}50.76456 \\
15.68285\end{array}$ \\
\hline 37 & 4122 & $\begin{array}{c}\text { Bystrzyca Kłodzka Forest District } \\
\text { Pokrzywno }\end{array}$ & B-Bystrzyca & $\begin{array}{c}50.3742 \\
16.50961\end{array}$ \\
\hline 38 & 40,049 & $\begin{array}{c}\text { Karkonosze National Park } \\
\text { Jagniątków }\end{array}$ & JAG-Jagniątków & $\begin{array}{l}50.82693 \\
15.63309\end{array}$ \\
\hline
\end{tabular}


Table 1. Cont.

\begin{tabular}{|c|c|c|c|c|}
\hline $\begin{array}{l}\text { Sample } \\
\text { Numer }\end{array}$ & $\begin{array}{l}\text { Clone } \\
\text { Numer }\end{array}$ & Seed Orchard Location & Abbreviation & $\begin{array}{c}\text { Geographical } \\
\text { Coordinates (N/E) }\end{array}$ \\
\hline 39 & 65 & $\begin{array}{c}\text { Kamienna Góra Forest District } \\
\text { Ogorzelec }\end{array}$ & KG_-Kamienna Góra & $\begin{array}{c}50.76653 \\
15.8967\end{array}$ \\
\hline 40 & 15 & $\begin{array}{c}\text { Kamienna Góra Forest District } \\
\text { Ogorzelec }\end{array}$ & KG_-Kamienna Góra & $\begin{array}{c}50.76653 \\
15.8967\end{array}$ \\
\hline 41 & 133 & $\begin{array}{c}\text { Śnieżka Forest District } \\
\text { Maciejowa }\end{array}$ & M-Maciejowa & $\begin{array}{l}50.91411 \\
15.82753\end{array}$ \\
\hline 42 & 6056 & $\begin{array}{l}\text { Zdroje Forest District } \\
\text { Duszniki }\end{array}$ & Z-Zdroje & $\begin{array}{l}50.40094 \\
16.39554\end{array}$ \\
\hline 43 & 5254 & $\begin{array}{c}\text { Jugów Forest District } \\
\text { Wojbórz }\end{array}$ & JUG—Jugów & $\begin{array}{c}50.5089 \\
16.63274\end{array}$ \\
\hline 44 & 60,086 & $\begin{array}{c}\text { Karkonosze National Park } \\
\text { Szklarska Poręba }\end{array}$ & SP_Szklarska Poręba & $\begin{array}{l}50.81837 \\
15.47205\end{array}$ \\
\hline 45 & 6094 & $\begin{array}{c}\text { Zdroje Forest District } \\
\text { Duszniki }\end{array}$ & Z-Zdroje & $\begin{array}{l}50.40094 \\
16.39554\end{array}$ \\
\hline 46 & 5314 & $\begin{array}{c}\text { Zdroje Forest District } \\
\text { Duszniki }\end{array}$ & Z-Zdroje & $\begin{array}{l}50.40094 \\
16.39554\end{array}$ \\
\hline 47 & 3125 & $\begin{array}{c}\text { Lądek Zdrój Forest District } \\
\text { Trzebieszowice }\end{array}$ & LZ_Lądek Zdrój & $\begin{array}{l}50.34253 \\
16.77332\end{array}$ \\
\hline 48 & 60,206 & $\begin{array}{c}\text { Karkonosze National Park } \\
\text { Szklarska Poręba }\end{array}$ & SP—Szklarska Poręba & $\begin{array}{l}50.81837 \\
15.47205\end{array}$ \\
\hline
\end{tabular}

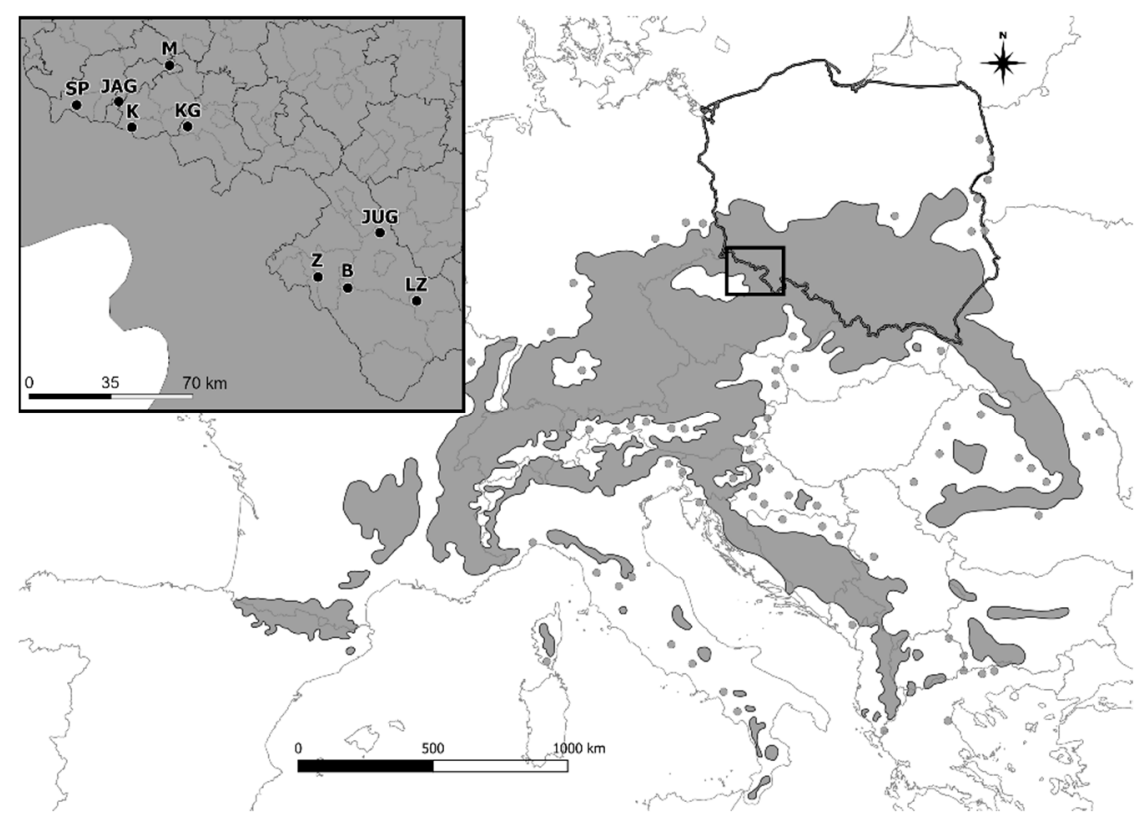

Figure 1. Distribution of Abies alba (source Euforgen [30]) and location of the seed orchards.

\subsection{Palynological Analysis}

Pollen was collected at the end of April 2019 from the selected grafts and pooled into a single sample representing the genotype. The plant material was stored in the herbarium of the Department of Forest Botany at the Poznan University of Life Sciences (PZNF). In accordance with the study by Wrońska-Pilarek et al. [31], each sample consisted of 30 randomly selected, mature, and correctly formed pollen grains derived from a single genotype. In total, 1440 pollen grains were subjected to the analysis.

The pollen grains were prepared for light (LM) and scanning electron microscopy (SEM) using the standard acetolysis method described by Erdtman [32]. The collected pollen grains were placed in 
tubes and then centrifuged with glacial acetic acid. Grains were mixed with the acetolysis solution, which consisted of 9 parts acetic anhydride and one part concentrated sulphuric acid. The mixture was then heated to boiling and kept in the water bath for 2-3 min. Samples were centrifuged in the acetolysis mixture, washed with acetic acid, and centrifuged again. The pollen grain samples were then mixed with $96 \%$ alcohol and centrifuged 4 times, with processed grains subsequently divided into two groups. One half of the processed sample was immersed in an alcohol-based solution of glycerin for LM, while the other was placed in 96\% ethyl alcohol in preparation for scanning electron microscopy (SEM). Morphological observations were carried out using both a digital light microscope (Levenhuk D320L, Tampa, FL, USA) and a scanning electron microscope (Jeol 7001TTLS, Akishima, Japan). Pollen grains were measured in a polar distal view at a magnification of $640 \times$. A total of 8 quantitative features of the pollen grains were analysed, i.e., the length of the polar axis $(P)$ and equatorial diameter (E), the width of the base of saccus (A) and length of the saccus $(B)$, the exine thickness (Ex), and $\mathrm{P} / \mathrm{E}, \mathrm{Ex} / \mathrm{P}$, and $\mathrm{A} / \mathrm{B}$ ratios. The pollen shape classes $(\mathrm{P} / \mathrm{E}$ ratio) were adopted according to the classification proposed by Erdtman [32]: Peroblate (less than 0.50), oblate (0.51-0.75), suboblate (0.76-0.88), oblate-spheroidal (0.89-0.99), spheroidal (1.00), prolate-spheroidal (1.01-1.14), and subprolate (1.15-1.33). The following qualitative features were also analysed: The corpus and saccus outlines, pollen shape, and exine ornamentation.

The descriptive terminology follows Punt et al. [33] and Halbritter et al. [34].

\subsection{Statistical Analysis}

\subsubsection{Genetic Analysis}

The hierarchical analysis of molecular variance (AMOVA) with individuals nested within locations (orchards) was performed in GenAlEx v. 6.2 (Acton, Australia) to examine the distribution of variation and differential connectivity among individuals, locations, and individuals within locations. The significance of the diversity distribution was tested with 9999 permutations. Additionally, the level of genetic variability and genetic relationships among individuals and locations was further analysed with principal component analysis (PCA) also in GenAlEx. The differentiation between the sampled locations was tested with 1000 permutations.

\subsubsection{Palynological Analysis}

The normality of the distributions of the observed traits (P, E, A, B, Exp, P/E, Exp/P, and A/B) was tested using Shapiro-Wilk's normality test [35]. Multivariate analysis of variance (MANOVA) was performed for all 8 observed traits jointly. Next, one-way analysis of variance (ANOVA) was carried out to determine the effects of Abies alba genotypes on the variability of $\mathrm{P}, \mathrm{E}, \mathrm{A}, \mathrm{B}, \mathrm{Exp}, \mathrm{P} / \mathrm{E}, \mathrm{Exp} / \mathrm{P}$, and $\mathrm{A} / \mathrm{B}$. The range values (minimal and maximal), mean values, and coefficients of variation of traits were calculated for all genotypes. Fisher's least significant differences (LSDs) were calculated for individual traits and on this basis, homogeneous groups of genotypes were determined. The relationships between observed traits were assessed on the basis of Pearson's correlation for means of genotypes. Relationships of observed traits were presented in the heatmap. Results were also analysed using multivariate methods. The canonical variate analysis was applied in order to present a multi-trait assessment of a similarity of tested genotypes in a lower number of dimensions with the least possible loss of information [36]. This makes it possible to illustrate the variation in genotypes in terms of all observed traits in the graphic form. Analysis of canonical variables is a statistical tool making it possible to solve the problem of multivariate relationships [37-40]. Mahalanobis' distance [41] was suggested as a measure of "polytrait" genotypes similarity [42], and its significance was verified by means of critical value $D_{\alpha}$ called "the least significant distance" [43]. Mahalanobis' distances were calculated for genotypes. The differences among analysed genotypes were verified by the cluster analysis using the nearest neighbour method and Euclidean distances. All the analyses were conducted using the GenStat 18th edition statistical software package. 


\section{Results}

\subsection{Genetic Variability}

All used nuclear single sequence repeats (nSSRs) loci were polymorphic and complete genotypes for almost all individuals obtained (Appendix A, Table A1). Despite numerous repeats, the SF1 locus in the Maciejowa location did not give the amplification results. The SF78 locus was most polymorphic having 21 alleles, while the least polymorphic was SF1 with four alleles. According to AMOVA, the highest proportion of molecular variance was found within individuals $(65 \%, p<0.05)$, while among individuals it was 32\% $(p<0.05)$, and only $3 \%$ concerned the inter-orchard level, but it was statistically significant $(p<0.05$, Table 2$)$. PCA conducted at the individual level showed an overlapping of genetic diversity ranges for individuals originating from different seed orchards (Figures 2 and 3 ). However, the analysis performed at the orchard level revealed a distinct character of three locations. The first principal coordinate (48.3\% of total variation) showed the separate character of Ladek Zdrój, Karpacz, and Maciejowa, while the second one (38\% of total variation) underlined a further distinction of the Maciejowa location.

Table 2. Analysis of molecular variances (AMOVA) based on nuclear single sequence repeats (nSSRs) in nine seed orchards.

\begin{tabular}{lclccc}
\hline \multicolumn{1}{c}{ Source } & df & \multicolumn{1}{c}{ SS } & MS & Est. var. & Percentage of Variation \\
\hline Among Pops & 8 & 29.481 & 3.685 & 0.071 & $3 \%$ \\
Among Indiv & 39 & 114.217 & 2.929 & 0.720 & $32 \%$ \\
Within Indiv & 48 & 71.500 & 1.490 & 1.490 & $65 \%$ \\
Total & 95 & 215.198 & & 2.280 & $100 \%$ \\
\hline
\end{tabular}

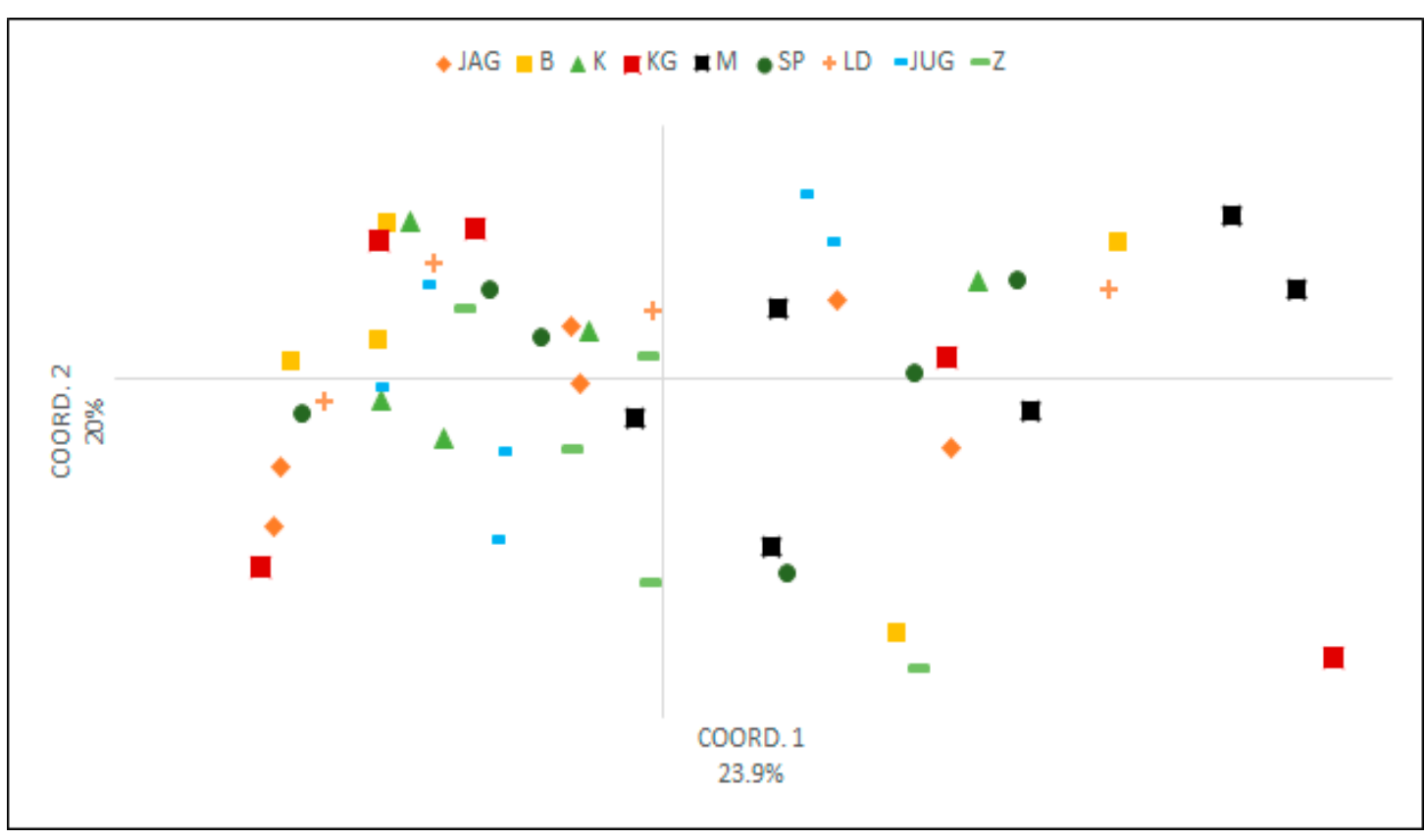

Figure 2. PCA on nSSRs conducted for 48 trees from nine seed orchards. 


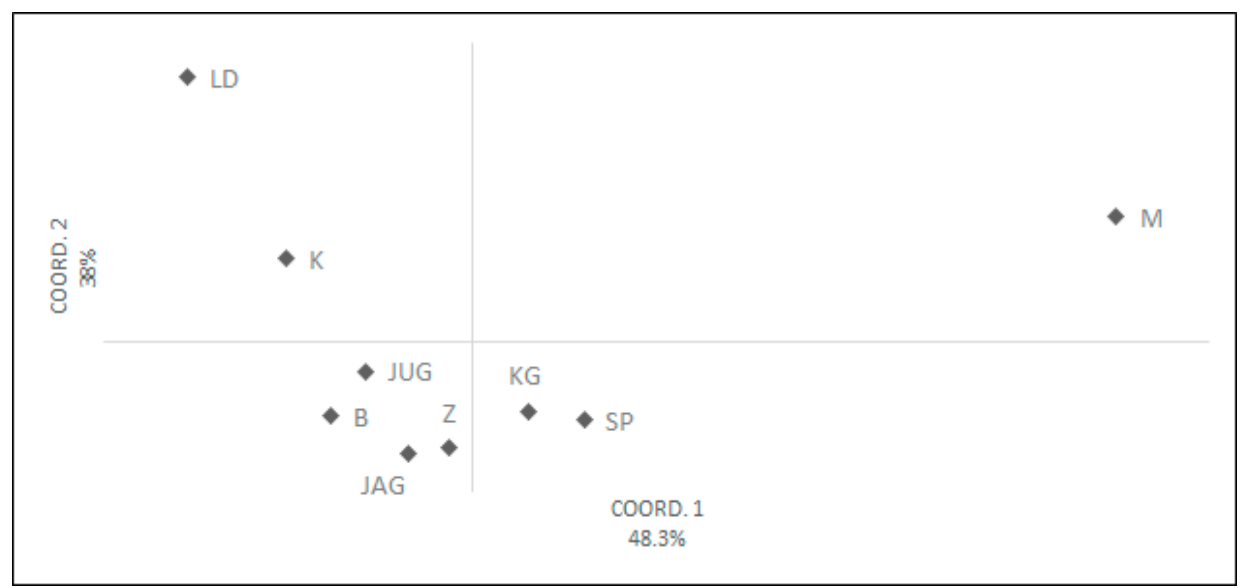

Figure 3. PCA on nSSRs conducted for seed orchards.

\subsection{General Morphological Description of Pollen}

Genotyping of the collected material with six microsatellites indicated that among the sampled individuals within each stand, distinct genotypes were present. Consequently, it assured that the analysis of pollen morphology involved distinct individuals. The genotypes of investigated individuals are given in the Appendix A.

A description of pollen grain morphology of the 48 genotypes (samples) of Abies alba under analysis is given below and illustrated in the SEM photographs (Figure 4A-F). The morphological observations for the quantitative features are summarised in Tables A2 and A3.
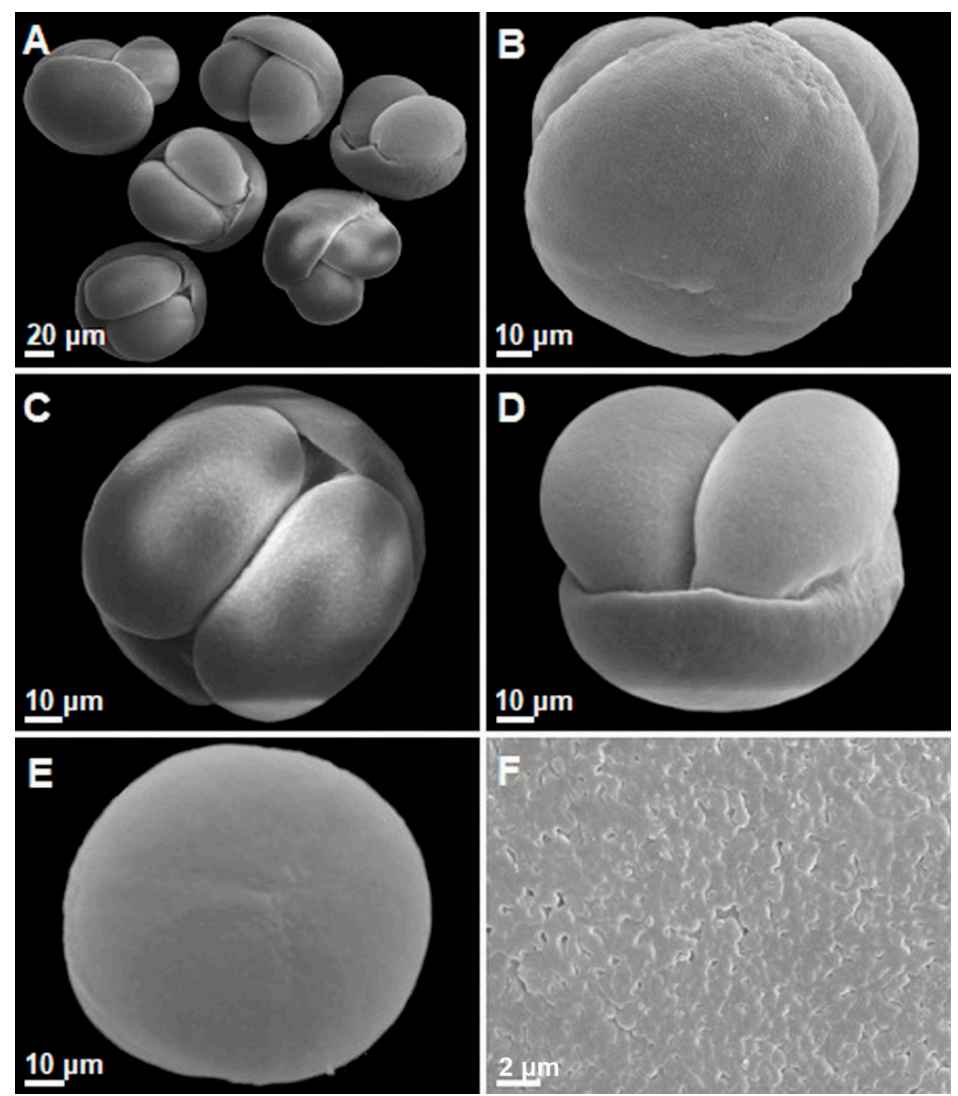

Figure 4. Pollen grains of Abies alba. (A)-group of pollen grains in the polar and equatorial view, (B) - polar proximal view, impression mark, (C) — two sacci in polar distal view, (D) — two sacci in equatorial view, (E) - polar proximal view, and (F)—psilate perforate exine surface. 
The pollen grains of investigated $A$. alba genotypes were isodiametric, heteropolar monads (Figure 4A-E). They were bisaccate, with one aperture leptoma. On the proximal face of the pollen grain, Y-shaped impression marks were found to be more or less distinct.

According to Erdtman's [44] pollen size classification, most of the investigated pollen grains were large $(97.36 \%)$ or very large $(2.64 \%)$, with the polar axis $(\mathrm{P})$ of the corpus (the central body of the pollen grains) ranging between 50.00 and $128.00 \mu \mathrm{m}$. The average value of $\mathrm{P}$ at the individual genotype level ranged from 73.10 to $92.50 \mu \mathrm{m}$. The widest range of this trait was observed in genotype $22(50.00-128.00 \mu \mathrm{m})$ and the smallest in genotype $12(62.00-84.00 \mu \mathrm{m})$. The shortest mean polar axis (P) was found in genotypes 12 and $13(73.10 \mu \mathrm{m}, 73.90 \mu \mathrm{m})$, while the longest was noted in genotypes 30 and $26(90.30 \mu \mathrm{m}, 92.50 \mu \mathrm{m})$ (Figure 5, Table A2).

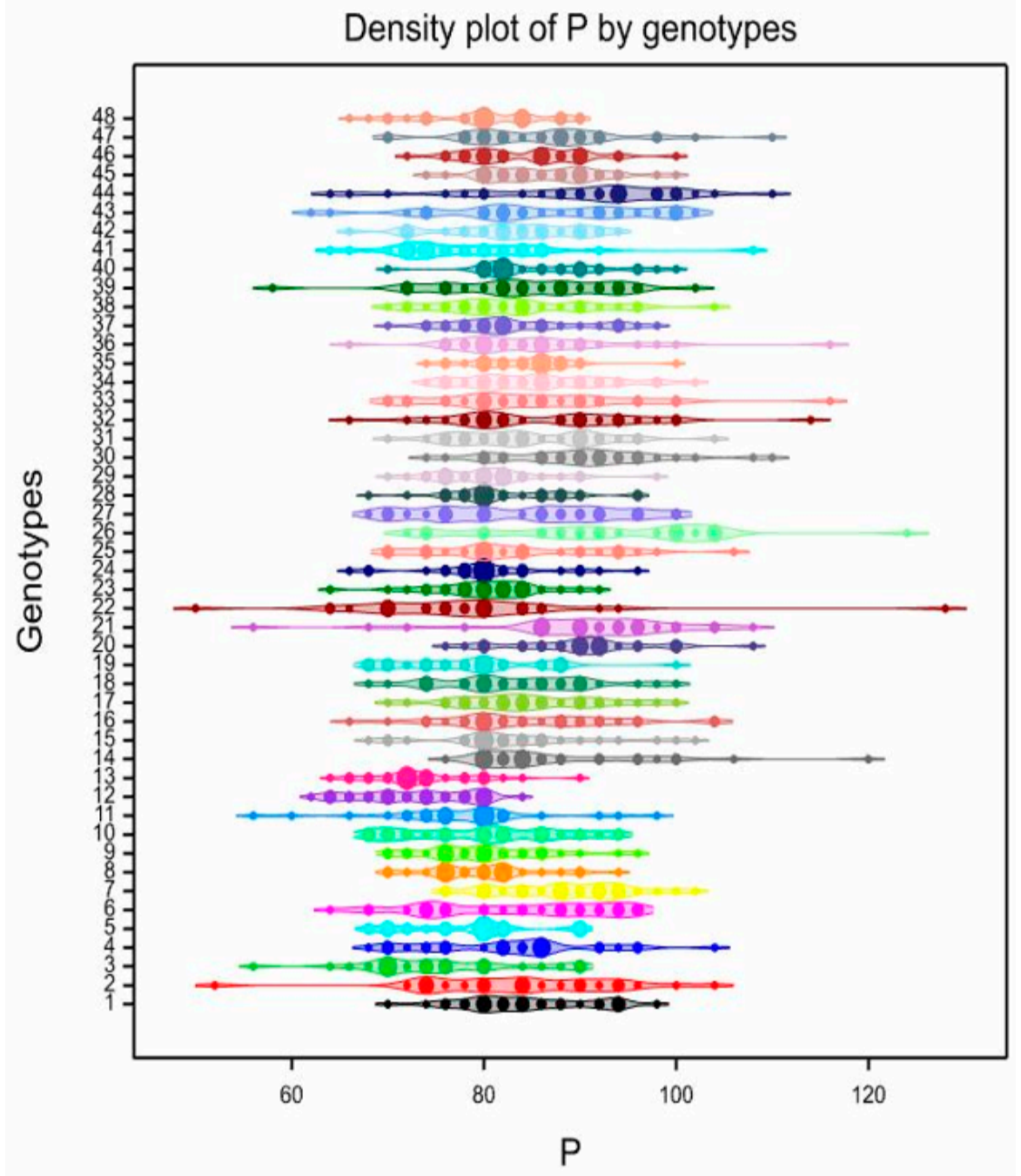

Figure 5. The density plot for the distribution of the shortest mean polar axis (P), classified by Abies alba genotypes. The observations are plotted along a line, with kernel density smoothed on either side to indicate the density of observations along the line. Numbers from 1 to 48 , see Table 1 .

Considering all the studied A. alba samples, the mean length of the equatorial diameter (E) of the pollen corpus was $100.29 \mu \mathrm{m}$, while the smallest value of this feature was $46.00 \mu \mathrm{m}$ (genotype 4) and the largest amounted to $146.00 \mu \mathrm{m}$ (genotype 44). The largest range of this trait was observed in genotype $4(46.00-124.00 \mu \mathrm{m})$ and the smallest in genotype $12(80.00-98.00 \mu \mathrm{m})$. The average value of E ranged from 82.90 to $113.90 \mu \mathrm{m}$ (in genotypes 13 and 30) (Table A2, Figure 6).

The pollen corpus outlined in the polar distal, proximal, and equatorial views was mostly elliptic and rarely circular (Figure $4 \mathrm{~A}-\mathrm{E}$ ). 


\section{Density plot of $\mathrm{E}$ by genotypes}

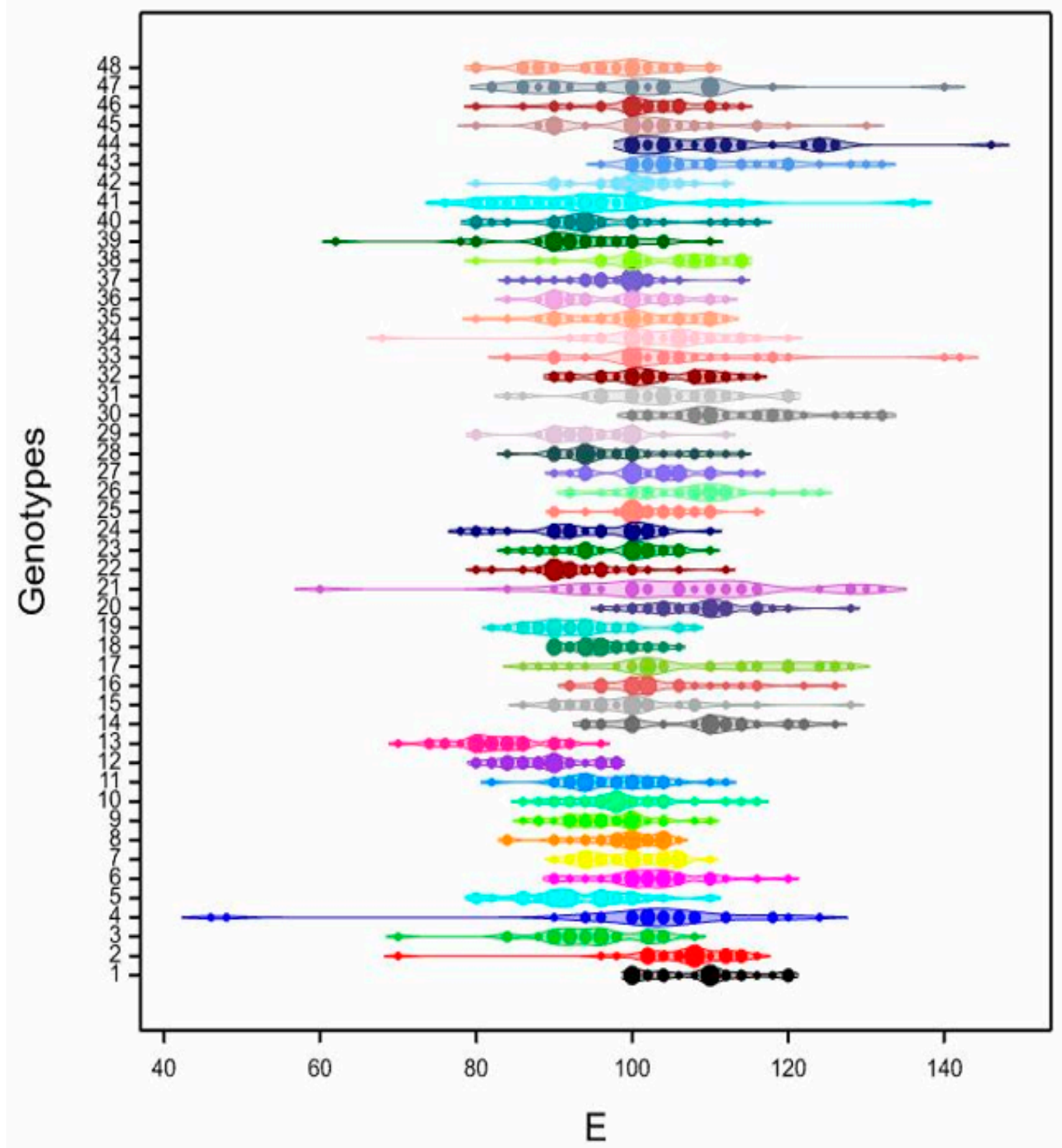

Figure 6. The density plot for the distribution of the mean length of the equatorial diameter (E), classified by Abies alba genotypes. Numbers from 1 to 48 , see Table 1 . Generally, the mean P/E ratio was 0.84 and ranged from 0.44 in genotype 44 to 1.83 in genotype 4 . On average, the smallest value of the $\mathrm{P} / \mathrm{E}$ ratio was in genotype $1(0.78)$ and the largest in genotype $39(0.91)$. The largest range of $\mathrm{P} / \mathrm{E}$ ratio was found in genotype 4 (0.65-1.83) and the smallest one in genotype 28 (0.71-0.92) (Table 3, Figure 7).

In all the genotypes of $A$. alba, suboblate (50.83\%), oblate-spheroidal (23.82\%), and oblate (19.38\%) pollen shape classes predominated. Rarely, prolate-spheroidal (3.40\%) and spheroidal (1.94\%) were noted. In seven pollen grains $(0.49 \%)$ and two other $(0.14 \%)$, subprolate and peroblate shapes were found, respectively.

Exine thickness of the corpus varied gradually. The thinnest was next to sacci in the leptoma area and the thickest in the cappa area. The mean exine thickness was $5.30 \mathrm{~mm}$, with a range of $2.00 \mathrm{~mm}$ in 76 genotypes up to $18.00 \mathrm{~mm}$ in genotype 31. On average, the exine was the thinnest in genotype 11 $(3.57 \mathrm{~mm})$, while the thickest was found in genotype $18(9.27 \mathrm{~mm})$. In total, the relative thickness of the exine (Ex/P ratio) was on average 0.06 (ranging from 0.02 to 0.2 ) (Table 3 ). 
Table 3. Minimal, maximal, and mean values as well as coefficient of variation (cv, in \%) for Exp, P/E, Exp/P, and A/B. In columns, means followed by the same letters are not significantly different.

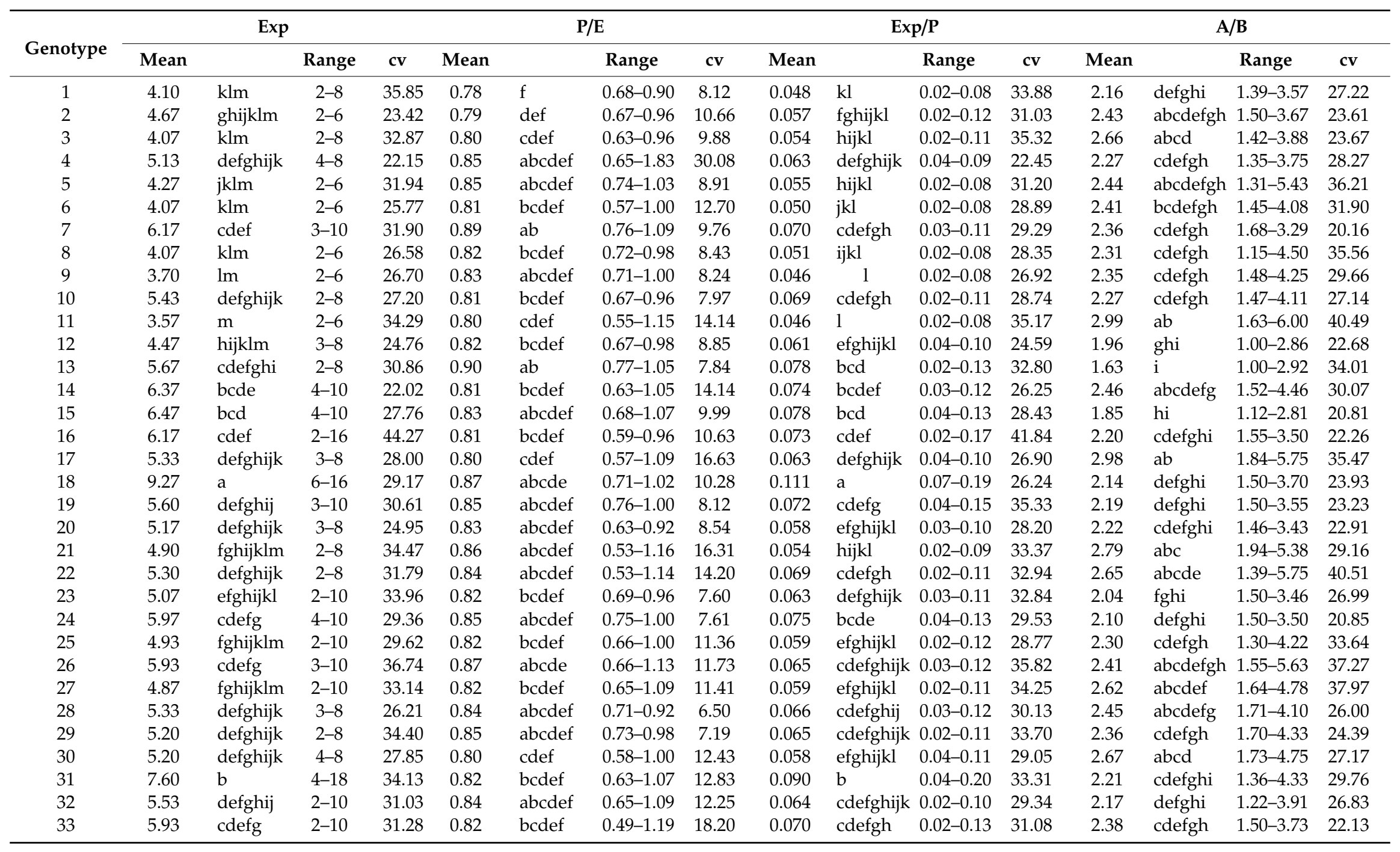


Table 3. Cont.

\begin{tabular}{|c|c|c|c|c|c|c|c|c|c|c|c|c|c|c|c|c|}
\hline \multirow{2}{*}{ Genotype } & \multicolumn{4}{|c|}{ Exp } & \multicolumn{4}{|c|}{$\mathrm{P} / \mathrm{E}$} & \multicolumn{4}{|c|}{ Exp/P } & \multicolumn{4}{|c|}{$\mathrm{A} / \mathrm{B}$} \\
\hline & Mean & & Range & $\mathrm{cv}$ & Mean & & Range & $\mathrm{cv}$ & Mean & & Range & $\mathrm{cv}$ & Mean & & Range & cv \\
\hline 34 & 4.43 & hijklm & $2-6$ & 29.44 & 0.84 & abcdef & $0.65-1.38$ & 15.72 & 0.052 & ijkl & $0.02-0.08$ & 28.32 & 2.32 & cdefgh & $1.36-3.54$ & 24.54 \\
\hline 35 & 5.73 & cdefgh & $2-8$ & 21.94 & 0.85 & abcdef & $0.72-1.00$ & 9.71 & 0.069 & cdefgh & $0.02-0.10$ & 22.91 & 2.42 & abcdefgh & $1.23-3.73$ & 24.11 \\
\hline 36 & 6.13 & cdef & $4-10$ & 26.99 & 0.88 & $a b c$ & $0.70-1.07$ & 11.69 & 0.072 & cdefg & $0.04-0.11$ & 25.48 & 2.19 & defghi & $1.44-3.46$ & 25.38 \\
\hline 37 & 5.63 & cdefghij & $2-8$ & 28.16 & 0.86 & abcdef & $0.07-1.00$ & 9.55 & 0.068 & cdefghi & $0.02-0.01$ & 26.66 & 2.06 & efghi & $1.5-3.545$ & 26.35 \\
\hline 38 & 4.63 & ghijklm & $2-6$ & 24.37 & 0.81 & bcdef & $0.66-1.00$ & 10.44 & 0.056 & ghijkl & $0.03-0.08$ & 23.74 & 2.34 & cdefgh & $1.45-4.00$ & 29.33 \\
\hline 39 & 4.80 & fghijklm & $2-8$ & 27.58 & 0.91 & $\mathrm{a}$ & $0.80-1.13$ & 8.75 & 0.058 & efghijkl & $0.02-0.10$ & 31.19 & 2.63 & abcde & $1.68-4.75$ & 25.66 \\
\hline 40 & 5.77 & cdefgh & $2-8$ & 31.44 & 0.91 & a & $0.71-1.17$ & 11.87 & 0.067 & cdefghi & $0.03-0.10$ & 30.11 & 2.42 & abcdefgh & $1.30-5.00$ & 32.13 \\
\hline 42 & 5.50 & defghij & $2-8$ & 24.69 & 0.84 & abcdef & $0.62-1.03$ & 11.13 & 0.067 & cdefghi & $0.02-0.11$ & 23.98 & 2.13 & defghi & $1.11-3.82$ & 28.91 \\
\hline 43 & 4.33 & ijklm & $2-6$ & 29.29 & 0.79 & ef & $0.55-1.00$ & 14.41 & 0.051 & $\mathrm{ijkl}$ & $0.02-0.08$ & 30.54 & 2.22 & cdefghi & $1.15-4.50$ & 32.14 \\
\hline 44 & 4.07 & $\mathrm{klm}$ & $2-6$ & 34.74 & 0.81 & bcdef & $0.44-1.00$ & 15.38 & 0.046 & 1 & $0.02-0.09$ & 39.97 & 3.00 & a & $1.67-5.63$ & 31.00 \\
\hline 45 & 4.97 & fghijkl & $3-8$ & 30.14 & 0.86 & abcdef & $0.72-1.04$ & 9.64 & 0.058 & efghijkl & $0.03-0.10$ & 31.57 & 2.25 & cdefgh & $1.55-4.50$ & 31.73 \\
\hline 46 & 5.10 & defghijk & $2-8$ & 25.41 & 0.84 & abcdef & $0.70-1.08$ & 9.21 & 0.061 & efghijkl & $0.02-0.11$ & 28.68 & 2.25 & cdefgh & $1.59-3.91$ & 28.27 \\
\hline 47 & 7.00 & $\mathrm{bc}$ & $4-10$ & 24.60 & 0.87 & abcd & $0.59-1.07$ & 15.28 & 0.081 & bc & $0.05-0.11$ & 21.85 & 2.18 & defghi & $1.42-4.73$ & 33.01 \\
\hline 48 & 5.40 & defghijk & $2-10$ & 39.09 & 0.84 & abcdef & $0.70-1.13$ & 9.98 & 0.068 & cdefghi & $0.02-0.12$ & 36.87 & 2.06 & efghi & $1.39-4.00$ & 33.29 \\
\hline $\mathrm{LSD}_{0.001}$ & \multicolumn{2}{|c|}{1.379} & \multicolumn{6}{|c|}{0.086} & \multicolumn{2}{|c|}{0.017} & \multicolumn{6}{|c|}{0.593} \\
\hline
\end{tabular}

LSD—least significant differences; ${ }^{* * *} p<0.001$. 


\section{Density plot of P/E by genotypes}

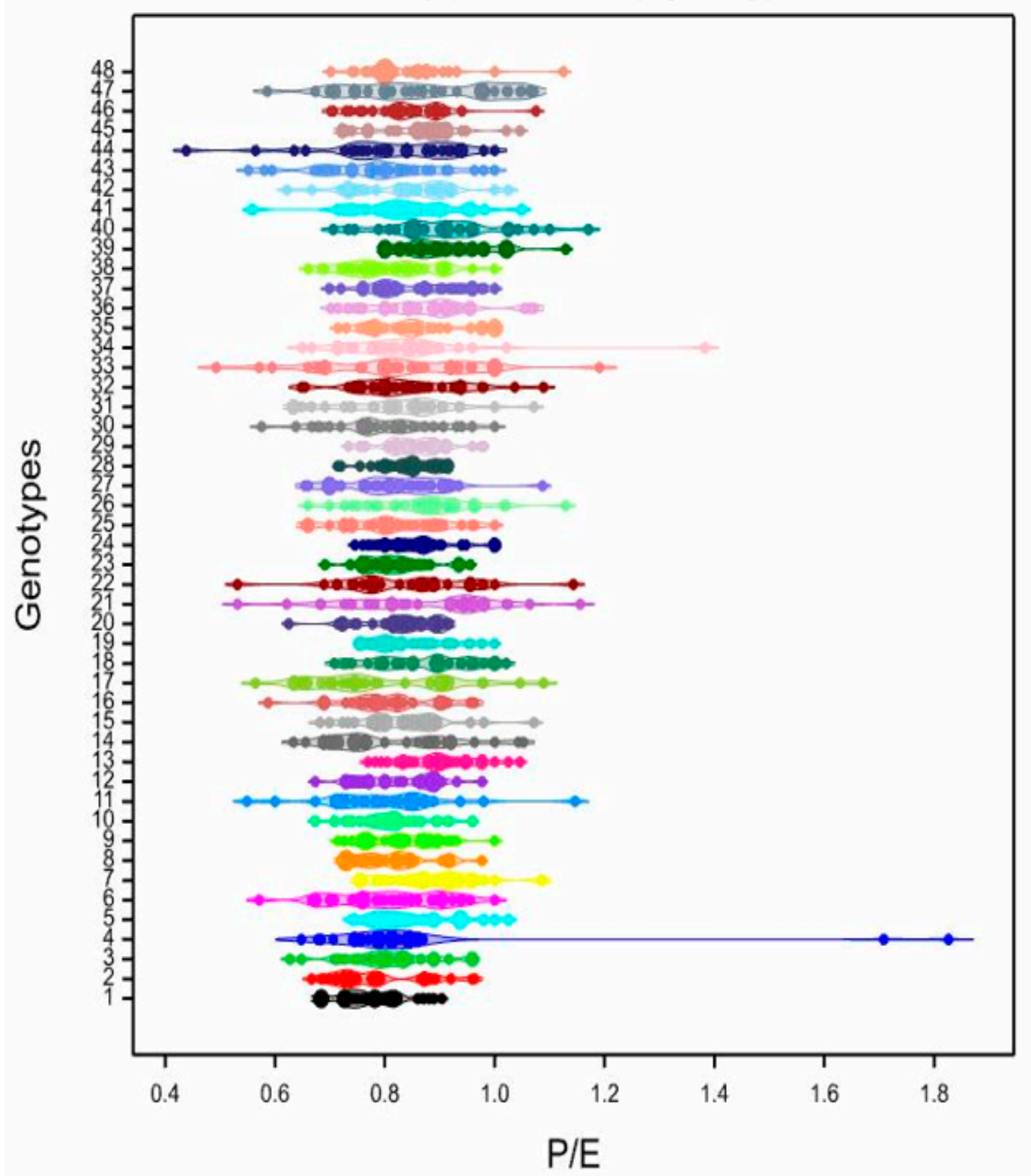

Figure 7. The density plot for the distribution of the shortest mean polar axis and the mean length of the equatorial diameter ratio (P/E), classified by Abies alba genotypes. Numbers from 1 to 48 , see Table 1 .

The exine surface was psilate, psilate with perforations and verrucate, or microverrucate. In the cappa area usually, a slightly more distinct exine surface (from psilate to verrucate or microverrucate) than in the leptoma area (psilate without perforations) was observed. The leptoma borders were verrucate or microverrucate. In the saccus, a mostly psilate exine surface, without or with perforations of different diameters were observed (Figure 4A-E).

The pollen grains of $A$. alba had two separate sacci, more or less equal in size. The average width of the saccus (A) was $73.46 \mu \mathrm{m}$, with extreme values of $40.00 \mu \mathrm{m}$ in genotype 42 and $118.00 \mu \mathrm{m}$ in genotype 36, and its average length (B) was $33.43 \mu \mathrm{m}$, (from $12.00 \mu \mathrm{m}$ in genotype 11 to $62.00 \mu \mathrm{m}$ in genotype 35 ). The mean $\mathrm{A} / \mathrm{B}$ ratio (saccus shape) was 2.34 and ranged from 1.00 in genotypes 12 and 13 to 6.00 in genotype 11 . This means that the saccus was usually much wider than being longer, elliptical, and flattened (Tables A2 and A3, Figure 4A-E and Figure 8). 


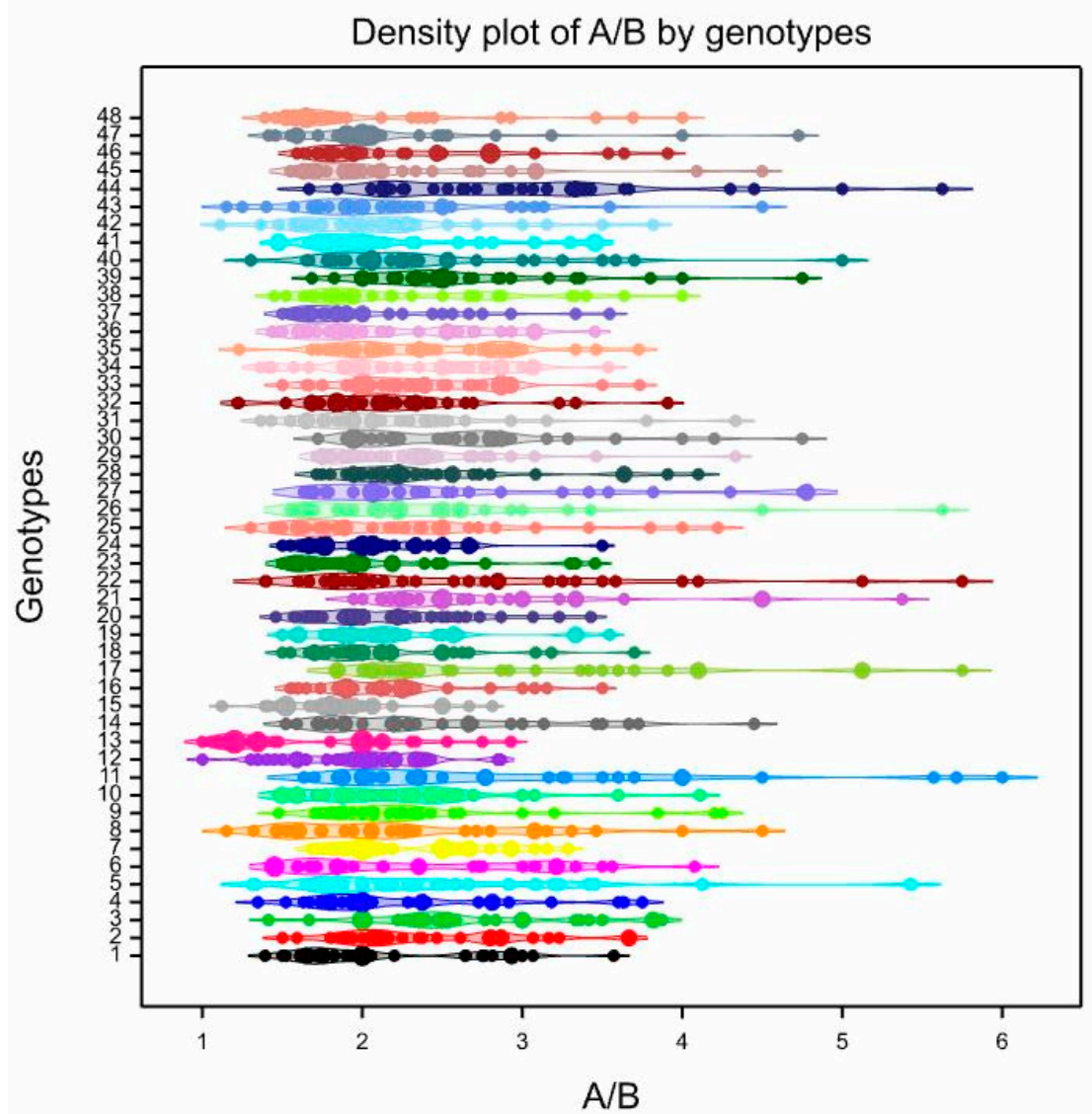

Figure 8. The density plot for the distribution of the average width of the saccus and average length ratio (A/B), classified by Abies alba genotypes. Numbers from 1 to 48 , see Table 1 .

The pollen grains under analysis usually had one aperture-leptoma. The leptoma was a thinning of the pollen wall on the distal face presumed to function as a germination area. It was located above the cappa (thick-walled proximal face of the corpus), and between the two sacci. The aperture was wide and trapezoidal in outline. The aperture membrane was usually thin, psilate without perforations, sometimes with single verrucae $(>1 \mu \mathrm{m})$, or microverrucae $(<1 \mu \mathrm{m})$, while the leptoma borders were usually covered with numerous verrucae or microverrucae.

\subsection{Pollen Variability of the Studied Genotypes}

The results of the MANOVA performed indicated that all A. alba genotypes were significantly different with regard to all eight quantitative traits (Wilk's $1=0.1998 ; F_{47 ; 1392}=6.59 ; p<0.0001$ ). The analysis of variance for the eight quantitative traits $\left(\mathrm{P}\left(F_{47 ; 1392}=7.72\right)\right.$, $\mathrm{E}\left(F_{47 ; 1392}=15.42\right)$, $\mathrm{A}\left(F_{47 ; 1392}=8.70\right), \mathrm{B}\left(F_{47 ; 1392}=7.30\right), \operatorname{Exp}\left(F_{47 ; 1392}=11.95\right), \mathrm{P} / \mathrm{E}\left(F_{47 ; 1392}=2.83\right), \operatorname{Exp} / \mathrm{P}\left(F_{47 ; 1392}=10.97\right)$, and $\mathrm{A} / \mathrm{B}\left(F_{47 ; 1392}=4.63\right)$ confirmed the variability of the tested genotypes at a significance level $\alpha=0.001$ (Tables A2 and A3). The range, mean values, and coefficients of the variation for the observed traits indicated a high variability among the tested genotypes, for which significant differences were found in terms of all the analysed quantitative traits (Tables A2 and A3). The average P of the tested genotypes ranged from 73.07 (genotype 12) to 92.53 (genotype 26), with an average of 83.26 (Table A2, Figure 5). We obtained 12 homogeneous groups of the genotypes for this trait. The value of $E$ ranged from 82.9 (genotype 13) to 113.9 (genotype 30), with an average of 100.3 (Table A2, Figure 6). We obtained 19 homogeneous groups of $A$. alba genotypes for E. The average A of the tested genotypes ranged from 64.4 (genotype 13) to 82.4 (genotype 29), with an average of 73.46 (Table A2). On the basis of obtained data, we observed 14 homogeneous groups of genotypes for trait $\mathrm{A}$. The values of $\mathrm{B}$ ranged 
from 26.27 (genotype 11) to 43.00 (genotype 13), with an average of 33.43 (Table A2). For this trait, we obtained 15 homogeneous groups of Abies genotypes.

The average Exp of the tested genotypes varied from 3.57 (genotype 11) to 9.27 (genotype 18), with an average of 5.3 (Table 3). We obtained 13 homogeneous groups of genotypes for Exp. The average $\mathrm{P} / \mathrm{E}$ of the tested genotypes varied from 0.78 (genotype 1) to 0.91 (genotype 39), with an average of 0.84 . Only six homogeneous groups of genotypes were obtained for $\mathrm{P} / \mathrm{E}$. The mean values of Exp/P ranged from 0.05 (genotypes 9, 11, and 44) to 0.11 (genotype 18), with an average of 0.06 (Table 3 ). We obtained 12 homogeneous groups of $A$. alba genotypes for Exp/P. The average A/B of the tested genotypes varied from 1.63 (genotype 13) to 3.00 (genotype 44), with an average of 2.34 (Table 3). The nine homogeneous groups of genotypes were obtained for trait $\mathrm{A} / \mathrm{B}$. The ranking of the variability of observed traits follows as $\operatorname{Exp}>\operatorname{Exp} / \mathrm{P}>\mathrm{A}>\mathrm{P}>\mathrm{B}>\mathrm{A} / \mathrm{B}>\mathrm{P} / \mathrm{E}$.

The correlation analysis performed indicated statistically significant correlation coefficients for 13 out of 28 coefficients (Figure 9). Trait P significantly correlated with $\mathrm{E}(r=0.800), \mathrm{A}(r=0.671)$, and A/B (0.292). Additionally, E correlated with A (0.647), P/E (-0.531), and A/B (0.401). Exp significantly correlated with $\mathrm{P} / \mathrm{E}(0.413), \operatorname{Exp} / \mathrm{P}(0.965)$, and $\mathrm{A} / \mathrm{B}(-0.363)$. Trait $\mathrm{A} / \mathrm{B}$ positively correlated with $\mathrm{A}$ $(0.342)$ and negatively with $B(-0.811)$ and $\operatorname{Exp} / \mathrm{P}(-0.451)$. The positive correlation was observed between Exp/P and P/E (0.402) (Figure 9).

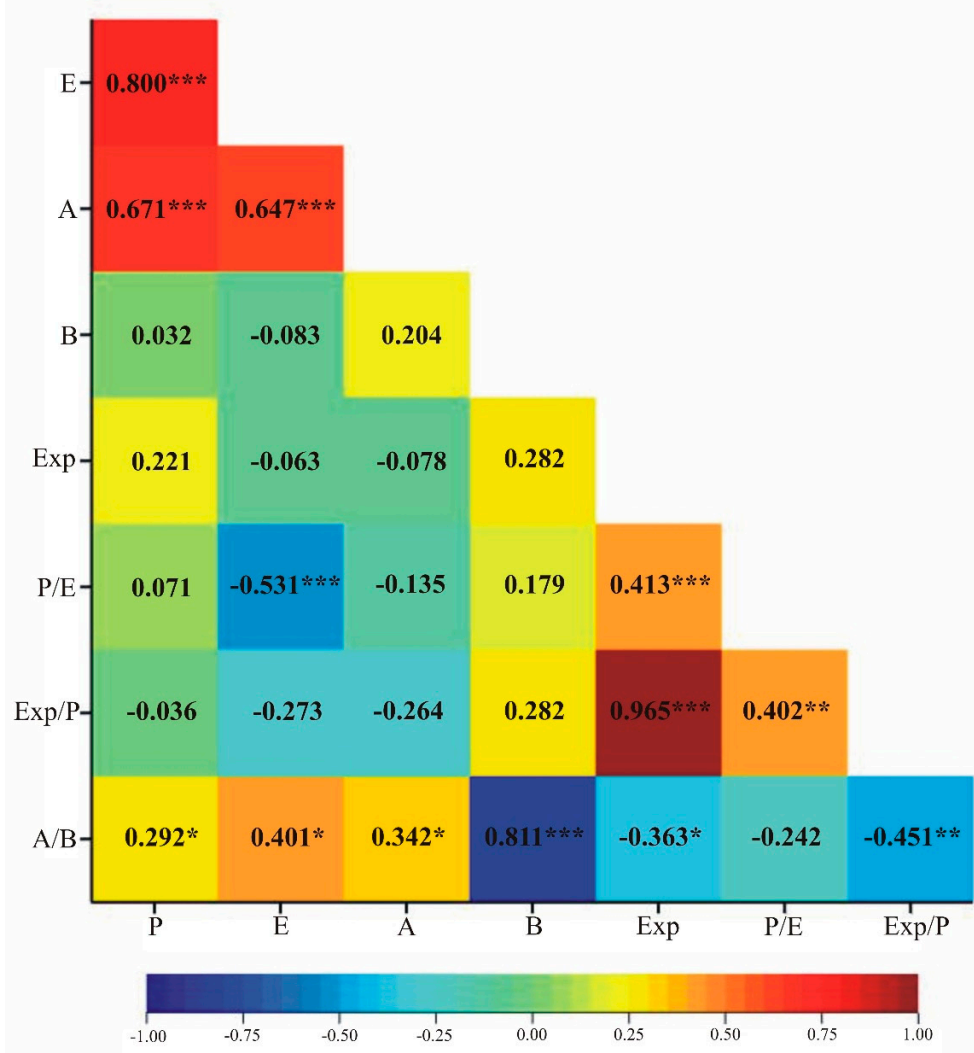

Figure 9. Heatmap for Pearson's linear correlation coefficients between observed traits (length of polar axis-P, equatorial diameter- $\mathrm{E}$, width of the base of saccus-A, length of saccus-B, exine thickness-Exp, and $\mathrm{P} / \mathrm{E}, \mathrm{Exp} / \mathrm{P}$ and $\mathrm{A} / \mathrm{B}$ ratios) of Abies alba genotypes. A heatmap is a data visualisation technique that shows the magnitude of a phenomenon as colour in two dimensions. The variation in colour may be by hue or intensity, giving obvious visual cues to the reader on how the phenomenon is clustered or varies over space. Magnitudes are laid out into a matrix of fixed cell size, with rows and columns as observed traits, and the sorting of rows and columns is intentional and somewhat arbitrary, with the goal of suggesting clusters or portraying them as discovered via statistical analysis. ${ }^{*} p<0.05 ;{ }^{* *} p<0.01 ;{ }^{* * *} p<0.001$. 
In the presented dendrogram, as a result of the nearest neighbour grouping using the Euclidean distances method, all examined $A$. alba genotypes were divided into four clusters (Figure 10). The first group contained only a single genotype, i.e., genotype 13, the second one genotypes 18 and 31 , while the third cluster grouped four genotypes: 17, 21, 30, and 44. All remaining genotypes belonged to the large fourth cluster (Figure 10).

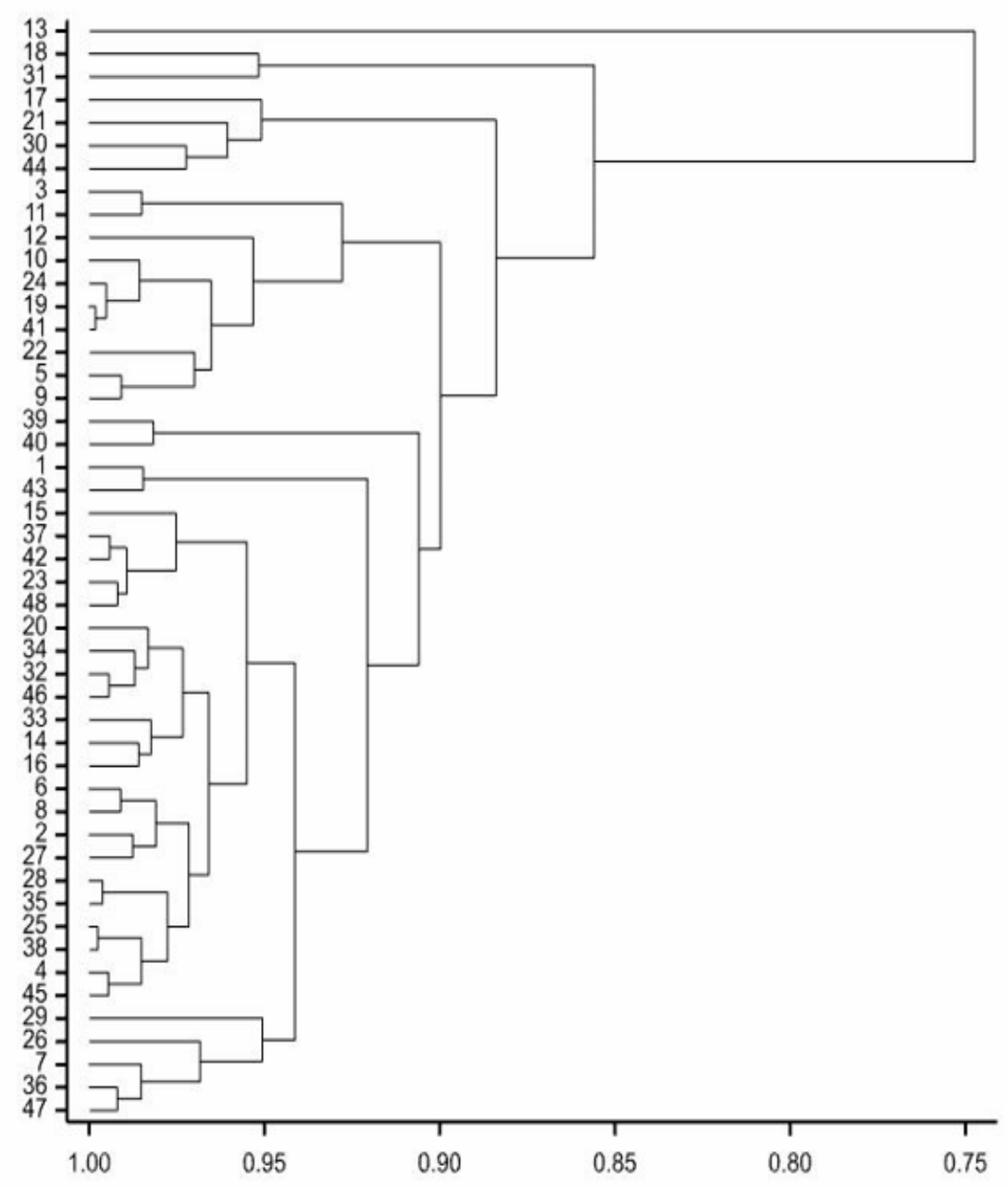

Figure 10. Dendrogram of differences between analysed Abies alba genotypes verified by the cluster analysis using the nearest neighbour method and Euclidean distances on the basis of eight traits (length of polar axis-P, equatorial diameter-E, width of the base of saccus-A, length of saccus-B, exine thickness-Exp, and P/E, Exp/P and A/B ratios). Numbers from 1 to 48, see Table 1.

Individual traits were of different importance and had a different share in the joint multivariate variation. The study on the multivariate variation for $A$. alba genotypes also included the identification of the most important traits in the multivariate variation of the genotypes. Figure 10 shows the variability of the eight quantitative traits of 48 studied $A$. alba genotypes. In the graph, the coordinates of the point for particular genotypes are the values for the first and second canonical variables. The first two canonical variables accounted jointly for $59.77 \%$ of the total multivariate variability between the individual genotypes (Table 4, Figure 11). The most significant, positive, linear relationship between the first canonical variable was found for $\mathrm{P} / \mathrm{E}$ and $\mathrm{Exp} / \mathrm{P}$ (Table 3). The first canonical variable negatively correlated with $\mathrm{P}, \mathrm{E}, \mathrm{A}$ and $\mathrm{A} / \mathrm{B}$ (Table 4). The second canonical variable significantly positively correlated with P, B, Exp, P/E, and Exp/P and negatively correlated with A/B (Table 4). The greatest variation in terms of all eight traits (measured by Mahalanobis distances) was found for genotypes 
13 and 30 (the Mahalanobis distance between them amounted to 4.69) (Table A3). The greatest similarity was found for genotypes 37 and 42 (0.44).

Table 4. Correlation coefficients between the first two canonical variables and original traits.

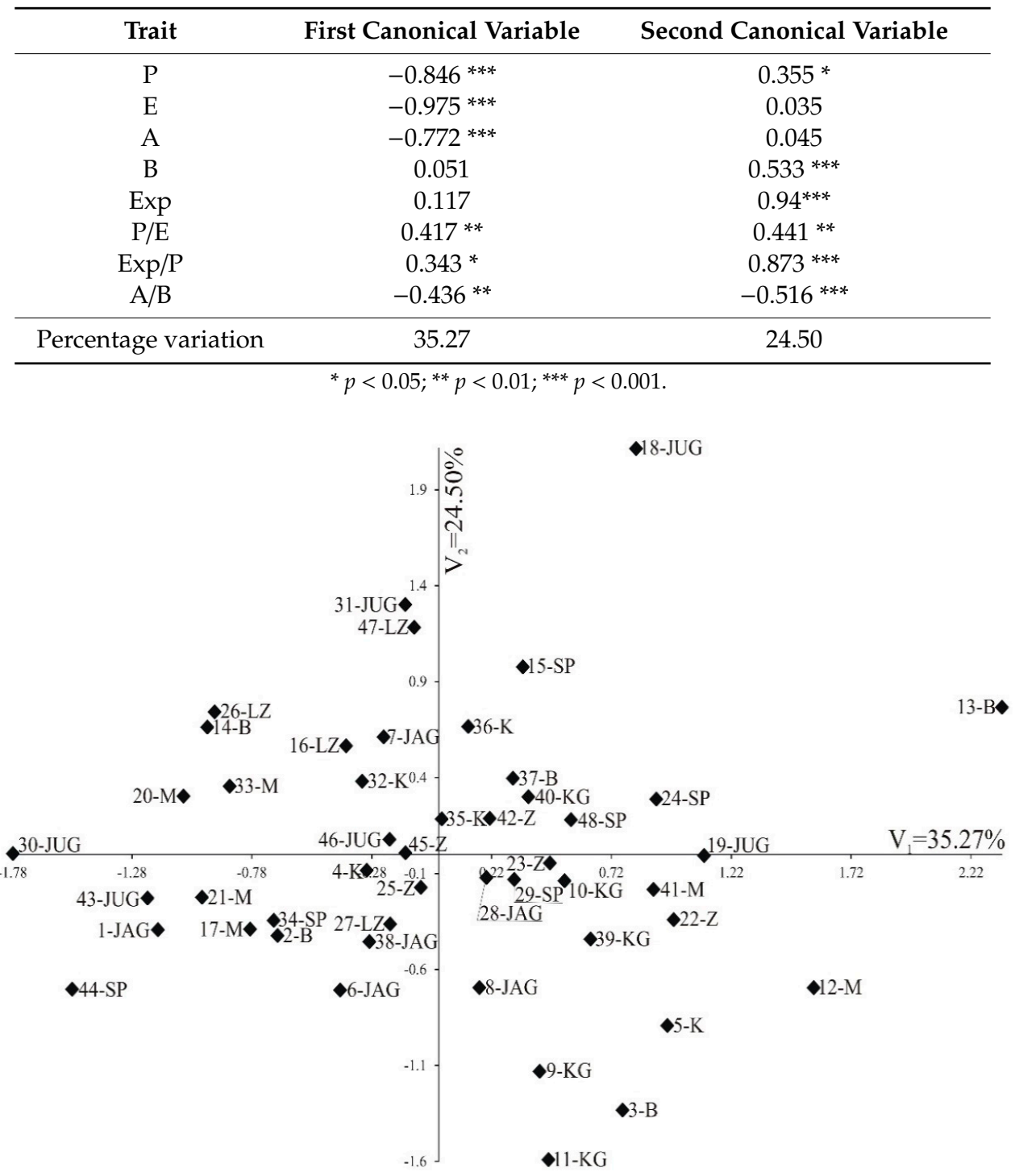

Figure 11. Distribution of 48 Abies alba genotypes in the space of the first two canonical variables. The coordinates of the point for particular genotypes are values of the first and second canonical variables, respectively. Numbers from 1 to 48 , see Table 1.

\section{Discussion}

The results of our study indicate that the pollen grains of Abies alba are more or less similar to other species from the genus Abies originating from either Europe or Asia [18-20,22-24,44,45]. However, pollen grains of $A$. alba possess some distinct features, which will be further discussed. Firs have large or very large, saccate pollen grains with one aperture, the leptoma, and impression mark. Pollen grains are usually more or less flattened and have perforate psilate or verrucate exine sculpture.

The scarcity of investigations dealing with the characteristics of pollen in A. alba prevent a detailed analysis or comparisons. Some limited results are available, but mostly they focus on pollen size (P and E) and shape (P/E) [19,21]. Gudeski [19] examined and compared pollen grains of A. alba from populations in Macedonia and of $A$. cephalonica from Parnis in Greece. Dobrinov and Gagov [21] studied morphology, viability, and storage of pollen from four native populations of A. alba in Bulgaria. 
However, the data provided by the authors on $\mathrm{P}, \mathrm{E}$, and the $\mathrm{P} / \mathrm{E}$ ratio are consistent with the information presented in this paper.

Our studies allowed us to define a few diagnostic features of $A$. alba pollen grains. Most of these features are also mentioned by other palynologists, except for one (saccus shape-A/B ratio), which we have described for the first time. Those traits are the exine surface of pollen corpus (cappa and leptoma) and sacci, the length of the polar axis (P), pollen shape (P/E ratio), and the saccus shape (A/B ratio). The prominent feature for the species from the genus Abies, in comparison to other conifers (e.g., genera Larix, Pinus, and Picea), is the Y-shaped impression mark on the pollen proximal face and the separated sacci, but these traits are not species-specific and are therefore not suitable for species-level analysis [18,22-24,26]. Faegri and Iversen [26] underlined in their study that the exine on the pollen proximal view in Abies is of considerable thickness and attains more than $5 \mu \mathrm{m}$. Our results confirmed this and showed that on average the mean exine thickness in A. alba genotypes was $5.30 \mu \mathrm{m}$.

The A. alba genotypes analysed in this study were not significantly differentiated in terms of the exine surface. The available data on this trait concerns other Abies species, and thus cannot be used in direct comparisons. However, in most of these papers, two types of exine surface (psilate or verrucate) and its smaller or larger variation, depending on the pollen area (cappa, leptoma, and sacci), were reported [22-25]. Additionally, Khan et al. [25] in two Asiatic species (A. pindrow and A. spectabilis) recorded the rugulate exine ornamentation.

The length of the polar axis $(\mathrm{P})$ allowed different clustering to be de defined among the investigated genotypes (large-50.01-100 $\mu \mathrm{m}$ and rarely very large $>100.01 \mu \mathrm{m}$ ) and the range of this feature (Figure 4). A similar range of the polar axis length was noted by Halbritter [22-24] in A. cephalonica, A. concolor, and A. nordmanniana. Asiatic species A. pindrow and A. spectabilis produce much smaller pollen grains having the $P$ range from 25 to $35 \mu \mathrm{m}$ [25].

The studied genotypes differed also with respect to the pollen shape (P/E ratio). Most of the pollen grain was oblate with less frequently rounded pollen grains being noted and only sporadically were elongated ones found (genotype 4 or 34 , Figure 5). The pollen grain shape has not been the objective of detailed investigations yet. In previous studies, we may find only results presenting the average value for the $\mathrm{P} / \mathrm{E}$ ratio or the range of this trait among different Abies species without concluding on the exact shape $[19,20,22-25]$. For example, the measurement made on a few Abies species (A. bracleafa, A. concolor, A. grandis, A. magnifica, and A. procera) from the Californian Peninsula [18] indicated the predominance of the elongated pollen grains (average $\mathrm{P} / \mathrm{E}$ ratio $>1.01$ ). In most studies, including this one, oblate pollen grains were found to be the most frequent $[20,22-25]$. Based on this limited data we may conclude that the values of the $\mathrm{P} / \mathrm{E}$ ratio reported here are comparable to published data, though in the case of our study the variability of this trait is much higher. This difference probably reflects the inter-species variability but may also stem from much wider sampling as each genotype was represented by 30 pollen grains, which was not a routine procedure in the past.

A new trait analysed in this study, the saccus shape (A/B), provided interesting results. Among the studied genotypes, none produced elongated sacci and only rarely could we find rounded ones (e.g., 12, 13, 42, and 43). On the other hand, in a majority of the investigated genotypes the sacci were flattened (1.5-three times wider than longer), and eight genotypes possessed significantly flattened sacci-even six times wider than longer (Figure 6). The variability of the $\mathrm{A} / \mathrm{B}$ trait is also substantial and the greatest was noted in genotypes $11,17,22$, and 44 . This trait turned out to be useful because it enabled a few genotypes to be distinguished. Up to date, the results on the saccus width are available for $A$. grandis [18]. That work reported an average value of this feature to be $79.93 \mu \mathrm{m}$, which is close to our results obtained for $A$. alba-73.46 $\mu \mathrm{m}$.

The results of the statistical analyses performed indicated that all studied A. alba genotypes were significantly different with regard to all eight quantitative pollen traits. Statistical analysis for these traits suggests a high variability among the tested genotypes. The most variable biometric traits were the equatorial diameter-E, exine thickness-Exp, and Exp/P ratio, while lower variability was found in the width of the saccus $-\mathrm{A}$, length of the polar axis $-\mathrm{P}$ and length of the saccus $-\mathrm{B}$, and the lowest 
variability were noted for the $\mathrm{A} / \mathrm{B}$ and $\mathrm{P} / \mathrm{E}$ ratios (Table $\mathrm{A} 2$ ). The outstanding diagnostic value can be ascribed to trait $\mathrm{E}$; the level of variability of this trait enabled to distinguish in $A$. alba genotypes a few pollen shape classes-from greatly oblate up to elongated.

Pollen grains from genotypes 13 (Bystrzyca Kłodzka) and 18 (from Jugów) were the most different because they had the smallest average values of traits $\mathrm{P}$ and $\mathrm{E}$. In addition, four other genotypes (11-from Kamienna Góra, 30 and 31-from Jugów, and 44-from Szklarska Poręba) were slightly different from the others. Genotype 30 was distinguished by high average values of $\mathrm{P}$ and $\mathrm{E}$, and 31 by $\mathrm{P}$ and $\mathrm{P} / \mathrm{E}$, while genotype 44 had significant values of $\mathrm{P}$ and $\mathrm{E}$, and low values of feature $\mathrm{A}$.

The analysis of localities from which the studied samples were collected showed (Figure 11) that similar pollen features occurred among samples collected from the same sites (e.g., 18 and 31 from Jugów) as well as from places distant from one another (e.g., 30 from Jugów and 44 from Szklarska Poręba). Similar results were obtained by Wrońska-Pilarek et al. [46,47] and Lechowicz et al. [48] in the palynological studies of selected species from the genera Crataegus, Quercus, and Rubus. In this way, results on the morphological variability correspond with genetic results, namely PCA performed on an individual level. However, the ordination of the seed orchards according to the first two axes in PCA revealed some differentiation between them, which was further supported by a significant genetic differentiation reaching 3\%. However, it needs to be clearly stressed that the results of the genetic analysis based on 4-5 individuals should be treated with caution. On the other hand, even such a small sample was able to deliver some preliminary insights into the genetic relationships between the locations. The lack of full correspondence between morphological and genetic data is not surprising if we consider the nature of those two data sets. The principal cause is the polygenic character of the morphological traits and the impact of environmental conditions on trait expression. In contrast, the single-gene SSRs markers possess their own genealogy that is governed by different neutral evolutionary processes.

\section{Conclusions}

1. The most important pollen grain features of the studied Abies alba genotypes are comprised of exine surface of pollen corpus (cappa and leptoma) and sacci, the length of the polar axis $(\mathrm{P})$, pollen shape ( $\mathrm{P} / \mathrm{E}$ ratio), and the new trait, saccus shape (A/B ratio).

2. The results of the presented study showed that the analysed morphological features of pollen grains from $48 \mathrm{~A}$. alba genotypes did not provide grounds to distinguish individual genotypes, except for a few of them, but were generally their groups.

3. Nevertheless, in our opinion the pollen of $A$. alba was the source of important characteristics at the species and genotype level. These results of the first study on the pollen morphology and variability of $A$. alba, could support further research on the reproduction of this valuable forest tree species.

Author Contributions: Conceptualization, D.W.-P., M.D., M.H.-K.; Material, M.H.-K., W.K., W.B.; Methodology, D.W.-P., M.D., M.H.-K.; Software, J.B.; Formal Analysis, D.W.-P., J.B., K.L.; Investigation, D.W.-P., M.D., M.H.-K.; Writing-Original Draft Preparation, D.W.-P., M.D., M.H.-K., K.L.; All authors have read and agreed to the published version of the manuscript.

Funding: The publication was co-financed within the framework of Ministry of Science and Higher Education programme as "Regional Initiative Excellence" in years 2019-2022, Project No. 005/RID/2018/19. This work was partly founded by Institute of Dendrology Polish Academy of Sciences.

Acknowledgments: We kindly thank Nuala Scanlon-Mederski (English native proofreader) for linguistic support and the technical staff of the Department of Silviculture (Poznan University of Life Sciences) for their participation in the plant material collection. We thank M. Łuczak for laboratory assistance. We would like to thank the reviewers for their detailed and valuable comments on the manuscript.

Conflicts of Interest: The authors declare no conflict of interest. 


\section{Appendix A}

Table A1. The analysed pollen grains for the studied genotypes of Abies alba individuals.

\begin{tabular}{|c|c|c|c|c|c|c|c|c|c|c|c|c|c|}
\hline Number & Genotype Number & Object/Seed Orchard Location & & & & & & & & & & & \\
\hline 1 & 40,077 & $\begin{array}{c}\text { Karkonosze National Park } \\
\text { Jagniątków }\end{array}$ & 224 & 224 & 118 & 128 & 168 & 168 & 160 & 226 & 164178 & 132 & 150 \\
\hline 2 & 4064 & $\begin{array}{c}\text { Forest District Bystrzyca Kłodzka } \\
\text { Pokrzywno }\end{array}$ & 221 & 224 & 108 & 108 & 168 & 168 & 244 & 260 & 170176 & 140 & 152 \\
\hline 3 & 4144 & $\begin{array}{c}\text { Forest District Bystrzyca Kłodzka } \\
\text { Pokrzywno }\end{array}$ & 224 & 224 & 108 & 112 & 172 & 172 & 238 & 264 & 154168 & 150 & 150 \\
\hline 4 & 20,011 & $\begin{array}{c}\text { Karkonosze National Park } \\
\text { Karpacz }\end{array}$ & 224 & 224 & 110 & 116 & 170 & 172 & 160 & 236 & 166194 & 146 & 146 \\
\hline 5 & 10,041 & $\begin{array}{c}\text { Karkonosze National Park } \\
\text { Karpacz }\end{array}$ & 221 & 224 & 110 & 110 & 170 & 170 & 174 & 236 & 152186 & 154 & 154 \\
\hline 6 & 40,019 & $\begin{array}{c}\text { Karkonosze National Park } \\
\text { Jagniątków }\end{array}$ & 224 & 221 & 110 & 110 & 168 & 178 & 248 & 248 & 166168 & 150 & 152 \\
\hline 7 & 40,036 & $\begin{array}{c}\text { Karkonosze National Park } \\
\text { Jagniątków }\end{array}$ & 224 & 224 & 110 & 110 & 170 & 172 & 206 & 240 & 154166 & 132 & 152 \\
\hline 8 & 40,056 & $\begin{array}{c}\text { Karkonosze National Park } \\
\text { Jagniątków }\end{array}$ & 221 & 224 & 108 & 116 & 172 & 176 & 240 & 248 & 165168 & 140 & 152 \\
\hline 9 & 87 & $\begin{array}{c}\text { Forest District Kamienna Góra } \\
\text { Ogorzelec }\end{array}$ & 224 & 224 & 110 & 110 & 168 & 168 & 206 & 248 & 162162 & 140 & 154 \\
\hline 10 & 142 & $\begin{array}{c}\text { Forest District Kamienna Góra } \\
\text { Ogorzelec }\end{array}$ & - & - & 108 & 114 & 172 & 172 & 234 & 234 & 170170 & 150 & 150 \\
\hline 11 & 127 & $\begin{array}{c}\text { Forest District Kamienna Góra } \\
\text { Ogorzelec }\end{array}$ & 224 & 224 & 112 & 112 & 168 & 168 & 176 & 178 & 172194 & 150 & 150 \\
\hline 12 & 24 & $\begin{array}{c}\text { Forest District Śnieżka } \\
\text { Maciejowa }\end{array}$ & - & - & 110 & 112 & 168 & 170 & 206 & 248 & 172186 & 150 & 150 \\
\hline 13 & 4063 & $\begin{array}{c}\text { Forest District Bystrzyca Kłodzka } \\
\text { Pokrzywno }\end{array}$ & 224 & 224 & 110 & 110 & 168 & 168 & 188 & 206 & 154166 & 140 & 148 \\
\hline 14 & 4002 & $\begin{array}{c}\text { Forest District Bystrzyca Kłodzka } \\
\text { Pokrzywno }\end{array}$ & 224 & 224 & 110 & 110 & 168 & 178 & 236 & 240 & 152170 & 148 & 148 \\
\hline 15 & 60,046 & $\begin{array}{c}\text { Karkonosze National Park } \\
\text { Szklarska Poręba }\end{array}$ & 224 & 224 & 108 & 114 & 168 & 170 & 160 & 250 & 170172 & 150 & 152 \\
\hline
\end{tabular}


Table A1. Cont.

\begin{tabular}{|c|c|c|c|c|c|c|c|c|c|c|c|c|c|}
\hline Number & Genotype Number & Object/Seed Orchard Location & & & & & & & & & & & \\
\hline 16 & 3021 & $\begin{array}{c}\text { Forest District Laadek Zdrój } \\
\text { Trzebieszowice }\end{array}$ & 206 & 221 & 110 & 110 & 176 & 176 & 174 & 246 & 152170 & 140 & 140 \\
\hline 17 & 198 & $\begin{array}{c}\text { Forest District Śnieżka } \\
\text { Maciejowa }\end{array}$ & - & - & 108 & 108 & 168 & 170 & 174 & 248 & 170178 & 140 & 140 \\
\hline 18 & 5341 & $\begin{array}{c}\text { Forest District Jugów } \\
\text { Wojbórz }\end{array}$ & 224 & 224 & 110 & 110 & 168 & 168 & 174 & 236 & 152152 & 150 & 160 \\
\hline 19 & 5335 & $\begin{array}{c}\text { Forest District Jugów } \\
\text { Wojbórz }\end{array}$ & 221 & 224 & 110 & 116 & 168 & 168 & 160 & 160 & 172172 & 142 & 142 \\
\hline 20 & 12 & $\begin{array}{c}\text { Forest District Śnieżka } \\
\text { Maciejowa }\end{array}$ & - & - & 110 & 110 & 168 & 170 & 160 & 206 & 170194 & 138 & 148 \\
\hline 21 & 235 & $\begin{array}{c}\text { Forest District Śnieżka } \\
\text { Maciejowa }\end{array}$ & - & - & 110 & 110 & 170 & 170 & 242 & 248 & 166168 & 152 & 152 \\
\hline 22 & 6031 & $\begin{array}{c}\text { Forest District Zdroje } \\
\text { Duszniki }\end{array}$ & 224 & 224 & 108 & 110 & 170 & 170 & 168 & 236 & 186186 & 142 & 150 \\
\hline 23 & 6078 & $\begin{array}{c}\text { Forest District Zdroje } \\
\text { Duszniki }\end{array}$ & 221 & 221 & 110 & 110 & 168 & 178 & 240 & 240 & 154154 & 150 & 152 \\
\hline 24 & 60,017 & $\begin{array}{c}\text { Karkonosze National Park } \\
\text { Szklarska Poręba }\end{array}$ & 221 & 224 & 108 & 108 & 168 & 168 & 242 & 248 & 166176 & 152 & 152 \\
\hline 25 & 6074 & $\begin{array}{c}\text { Forest District Zdroje } \\
\text { Duszniki }\end{array}$ & 224 & 224 & 110 & 112 & 168 & 176 & 250 & 250 & 166166 & 142 & 142 \\
\hline 26 & 3014 & $\begin{array}{c}\text { Forest District Lądek Zdrój } \\
\text { Trzebieszowice }\end{array}$ & 224 & 224 & 110 & 110 & 170 & 172 & 194 & 194 & 166178 & 140 & 140 \\
\hline 27 & 3158 & $\begin{array}{c}\text { Forest District Laadek Zdrój } \\
\text { Trzebieszowice }\end{array}$ & 221 & 221 & 112 & 112 & 168 & 176 & 240 & 248 & 152170 & 140 & 140 \\
\hline 28 & 40,073 & $\begin{array}{c}\text { Karkonosze National Park } \\
\text { Jagniątków }\end{array}$ & 224 & 224 & 110 & 116 & 168 & 170 & 174 & 242 & 168168 & 140 & 152 \\
\hline 29 & 60,135 & $\begin{array}{c}\text { Karkonosze National Park } \\
\text { Szklarska Poręba }\end{array}$ & 221 & 224 & 110 & 110 & 168 & 170 & 160 & 250 & 154192 & 150 & 152 \\
\hline 30 & 5347 & $\begin{array}{c}\text { Forest District Jugów } \\
\text { Wojbórz }\end{array}$ & 224 & 224 & 110 & 110 & 168 & 174 & 194 & 226 & 166166 & 150 & 150 \\
\hline 31 & 5262 & $\begin{array}{c}\text { Forest District Jugów } \\
\text { Wojbórz }\end{array}$ & 221 & 224 & 110 & 110 & 172 & 172 & 174 & 174 & 152170 & 152 & 152 \\
\hline 32 & 10,038 & $\begin{array}{c}\text { Karkonosze National Park } \\
\text { Karpacz }\end{array}$ & 221 & 224 & 108 & 108 & 168 & 170 & 194 & 250 & 152194 & 140 & 144 \\
\hline
\end{tabular}


Table A1. Cont.

\begin{tabular}{|c|c|c|c|c|c|c|c|c|c|c|c|c|c|}
\hline Number & Genotype Number & Object/Seed Orchard Location & & & & & & & & & & & \\
\hline \multirow{2}{*}{33} & \multirow{2}{*}{78} & Forest District Śnieżka & & & & & & & & & & & \\
\hline & & Maciejowa & 221 & 224 & 110 & 112 & 170 & 172 & 226 & 250 & 170178 & 150 & 150 \\
\hline \multirow{2}{*}{34} & \multirow{2}{*}{60,002} & Karkonosze National Park & & & & & & & & & & & \\
\hline & & Szklarska Poręba & 221 & 224 & - & - & 172 & 172 & 178 & 242 & 178178 & 148 & 154 \\
\hline \multirow{2}{*}{35} & \multirow{2}{*}{30,006} & Karkonosze National Park & & & & & & & & & & & \\
\hline & & Karpacz & 224 & 224 & 110 & 116 & 168 & 172 & 174 & 246 & 152178 & 140 & 140 \\
\hline \multirow{2}{*}{36} & \multirow{2}{*}{20,019} & Karkonosze National Park & & & & & & & & & & & \\
\hline & & Karpacz & 224 & 224 & 110 & 110 & 168 & 168 & 242 & 250 & 152178 & 140 & 146 \\
\hline \multirow[b]{2}{*}{37} & \multirow{2}{*}{4122} & Forest District Bystrzyca Kłodzka & & & & & & & & & & & \\
\hline & & Pokrzywno & 224 & 224 & 110 & 110 & 174 & 174 & 206 & 226 & 166196 & 140 & 152 \\
\hline \multirow{2}{*}{38} & \multirow{2}{*}{40,049} & Karkonosze National Park & & & & & & & & & & & \\
\hline & & Jagniątków & 224 & 224 & 110 & 110 & 172 & 172 & 242 & 250 & 152166 & 132 & 152 \\
\hline \multirow{2}{*}{39} & \multirow{2}{*}{65} & Forest District Kamienna Góra & & & & & & & & & & & \\
\hline & & Ogorzelec & 224 & 224 & 110 & 110 & 172 & 172 & 236 & 236 & 186186 & 146 & 152 \\
\hline \multirow{2}{*}{40} & \multirow{2}{*}{15} & Forest District Kamienna Góra & & & & & & & & & & & \\
\hline & & Ogorzelec & 221 & 224 & 110 & 110 & 168 & 168 & 236 & 250 & 166166 & 146 & 146 \\
\hline \multirow{2}{*}{41} & \multirow[b]{2}{*}{133} & Forest District Śnieżka & & & & & & & & & & & \\
\hline & & Maciejowa & - & - & 108 & 116 & 168 & 168 & 160 & 160 & 164164 & 146 & 152 \\
\hline \multirow[b]{2}{*}{42} & \multirow[b]{2}{*}{6056} & Forest District Zdroje & & & & & & & & & & & \\
\hline & & Duszniki & 224 & 224 & 110 & 112 & 172 & 172 & 206 & 248 & 168170 & 144 & 144 \\
\hline \multirow{2}{*}{43} & \multirow{2}{*}{5254} & Forest District Jugów & & & & & & & & & & & \\
\hline & & Wojbórz & 206 & 221 & 110 & 110 & 172 & 178 & 178 & 236 & 166172 & 148 & 156 \\
\hline \multirow{2}{*}{44} & \multirow{2}{*}{60,086} & Karkonosze National Park & & & & & & & & & & & \\
\hline & & Szklarska Poręba & 224 & 224 & 110 & 110 & 170 & 170 & 240 & 250 & 178178 & 152 & 152 \\
\hline \multirow{2}{*}{45} & \multirow[b]{2}{*}{6094} & Forest District Zdroje & & & & & & & & & & & \\
\hline & & Duszniki & 224 & 224 & 114 & 114 & 172 & 172 & 248 & 248 & 176176 & 150 & 150 \\
\hline & & Forest District Jugów & & & & & & & & & & & \\
\hline 46 & 5314 & Wojbórz & 224 & 224 & 108 & 116 & 168 & 170 & 206 & 206 & 152172 & 140 & 140 \\
\hline & & Forest District Lądek Zdrój & & & & & & & & & & & \\
\hline 47 & 3125 & Trzebieszowice & 224 & 224 & 110 & 110 & 168 & 170 & 164 & 250 & 176176 & 140 & 140 \\
\hline 48 & 60,206 & Karkonosze National Park & & & & & & & & & & & \\
\hline 48 & $00, \angle 00$ & Szklarska Poręba & 224 & 224 & 110 & 110 & 168 & 170 & 160 & 160 & 180180 & 140 & 150 \\
\hline
\end{tabular}


Table A2. Minimal, maximal, and mean values as well as coefficient of variation (cv, in \%) for P, E, A and B. In columns, means followed by the same letters are not significantly different.

\begin{tabular}{|c|c|c|c|c|c|c|c|c|c|c|c|c|c|c|c|c|}
\hline \multirow{2}{*}{ Genotype } & \multicolumn{4}{|c|}{$\mathbf{P}$} & \multicolumn{4}{|c|}{$\bar{E}$} & \multicolumn{4}{|c|}{$\mathbf{A}$} & \multicolumn{4}{|c|}{ B } \\
\hline & Mean & & Range & cv & Mean & & Range & $\mathrm{cv}$ & Mean & & Range & $\mathrm{cv}$ & Mean & & Range & $\mathrm{cv}$ \\
\hline 1 & 84.33 & bcdefghi & $70-98$ & 8.19 & 108.5 & abcde & $100-120$ & 6.01 & 82.27 & $\mathrm{a}$ & 64-104 & 13.67 & 39.53 & $a b$ & $28-50$ & 15.13 \\
\hline 2 & 83.53 & bcdefghi & $52-104$ & 12.41 & 106.1 & bcdefghi & $70-116$ & 7.90 & 76.07 & abcdefghij & 56-92 & 12.09 & 32.33 & cdefghijklmn & $24-44$ & 16.73 \\
\hline 3 & 75.47 & $\mathrm{jkl}$ & $56-90$ & 10.85 & 94.7 & opqr & $70-108$ & 8.04 & 71 & fghijklmn & $56-86$ & 11.69 & 28 & mno & $16-48$ & 23.73 \\
\hline 4 & 82.6 & efghi & 68-104 & 10.77 & 101.1 & fghijklmno & $46-124$ & 16.50 & 71.33 & efghijklmn & $60-90$ & 12.37 & 33.13 & cdefghijklm & $20-52$ & 22.79 \\
\hline 5 & 78.33 & hijkl & $68-90$ & 8.32 & 93 & pqr & $80-110$ & 7.51 & 67.33 & klmn & $42-84$ & 12.99 & 30 & ijklmno & $14-54$ & 26.95 \\
\hline 6 & 83 & defghi & $64-96$ & 11.49 & 102.7 & defghijklm & $90-120$ & 6.78 & 76.67 & abcdefghi & 58-114 & 20.25 & 33.47 & cdefghijklm & $22-44$ & 19.15 \\
\hline 7 & 88.4 & abcde & $76-102$ & 7.71 & 99.6 & ghijklmnopq & 90-110 & 5.31 & 79.07 & abcd & $60-92$ & 11.05 & 34.53 & bcdefghijk & $26-50$ & 17.99 \\
\hline 8 & 80 & fghijkl & $70-94$ & 7.19 & 98.3 & jklmnopq & $84-106$ & 5.82 & 76.07 & abcdefghij & $62-90$ & 10.91 & 35.8 & bcdefghi & $20-54$ & 24.70 \\
\hline 9 & 80.27 & fghijk & $70-96$ & 8.11 & 96.8 & klmnopq & $86-110$ & 5.91 & 68.73 & jklmn & $52-100$ & 15.80 & 30.47 & ghijklmno & $16-46$ & 18.86 \\
\hline 10 & 80 & fghijkl & $68-94$ & 10.13 & 98.8 & ijklmnopq & $86-116$ & 7.26 & 65.73 & $\operatorname{lmn}$ & 48-82 & 12.55 & 30.33 & hijklmno & $18-44$ & 19.67 \\
\hline 11 & 77.8 & ijkl & $56-98$ & 11.08 & 97.8 & klmnopq & $82-112$ & 6.50 & 70.27 & hijklmn & $58-80$ & 9.80 & 26.27 & o & $12-38$ & 29.23 \\
\hline 12 & 73.07 & 1 & $62-84$ & 8.28 & 89.1 & rs & $80-98$ & 6.00 & 65.2 & $\mathrm{mn}$ & $52-80$ & 12.31 & 34.27 & bcdefghijkl & $26-56$ & 16.84 \\
\hline 13 & 73.93 & $\mathrm{kl}$ & $64-90$ & 7.67 & 82.9 & $\mathrm{~s}$ & 70-96 & 7.19 & 64.4 & $\mathrm{n}$ & $54-86$ & 11.22 & 43 & $\mathrm{a}$ & $24-60$ & 27.90 \\
\hline 14 & 87.8 & abcde & $76-120$ & 10.99 & 108.9 & abcd & $94-126$ & 8.08 & 76.73 & abcdefghi & 64-98 & 12.37 & 33.07 & cdefghijklm & $22-44$ & 21.94 \\
\hline 15 & 83.2 & cdefghi & 68-102 & 9.95 & 100.1 & ghijklmnop & $86-128$ & 8.68 & 67.67 & klmn & $50-90$ & 11.28 & 37.6 & abcd & $24-50$ & 17.24 \\
\hline 16 & 84.53 & bcdefghi & 66-104 & 10.74 & 104.1 & cdefghijk & $92-126$ & 7.96 & 75.47 & abcdefghij & $64-90$ & 10.69 & 35.33 & bcdefghij & $24-44$ & 14.82 \\
\hline 17 & 84.67 & bcdefghi & $70-100$ & 8.69 & 107.9 & abcdef & $86-128$ & 11.33 & 73.53 & cdefghijk & $62-92$ & 10.42 & 26.67 & no & $16-38$ & 24.15 \\
\hline 18 & 83.4 & bcdefghi & $68-100$ & 9.57 & 96.2 & lmnopqr & 90-106 & 4.71 & 69.4 & ijklmn & $56-84$ & 9.99 & 33.47 & cdefghijklm & $20-40$ & 15.21 \\
\hline 19 & 78.8 & ghijkl & $68-100$ & 9.53 & 93.1 & pqr & $82-108$ & 6.93 & 65.07 & $\mathrm{mn}$ & $50-80$ & 13.40 & 30.73 & fghijklmno & $18-52$ & 20.90 \\
\hline 20 & 89.87 & abcd & $76-108$ & 7.97 & 108.8 & abcd & $96-128$ & 6.43 & 76 & abcdefghij & $60-96$ & 11.63 & 35.4 & bcdefghij & $26-48$ & 16.60 \\
\hline 21 & 90.13 & $a b c$ & 56-108 & 11.98 & 106.2 & bcdefgh & 60-132 & 14.20 & 77.47 & abcdefgh & $64-90$ & 7.70 & 29.4 & klmno & $16-36$ & 20.62 \\
\hline 22 & 78.13 & hijkl & $50-128$ & 16.63 & 93.2 & pqr & $80-112$ & 6.96 & 71.8 & defghijklmn & 56-92 & 13.21 & 29.87 & jklmno & $16-46$ & 25.96 \\
\hline 23 & 80.13 & fghijk & 64-92 & 7.27 & 97.6 & klmnopq & $84-110$ & 6.82 & 70.47 & ghijklmn & $60-86$ & 8.15 & 36.27 & bcdefg & $20-48$ & 19.68 \\
\hline 24 & 80.4 & fghijk & $66-96$ & 8.27 & 94.7 & opqr & $78-110$ & 8.54 & 65.2 & $\mathrm{mn}$ & $54-84$ & 11.49 & 31.93 & defghijklmno & $24-44$ & 18.50 \\
\hline 25 & 83.53 & bcdefghi & $70-106$ & 10.83 & 102.3 & defghijklmn & $90-116$ & 5.53 & 70.2 & hijklmn & $60-94$ & 11.70 & 32.93 & cdefghijklm & $18-50$ & 25.46 \\
\hline 26 & 92.53 & $a^{\circ}$ & $72-124$ & 12.87 & 106.9 & abcdefg & $92-124$ & 7.20 & 78.93 & abcde & $62-96$ & 12.41 & 35.13 & bcdefghijk & $16-46$ & 20.37 \\
\hline 27 & 83.67 & bcdefghi & $68-100$ & 11.44 & 102.3 & defghijklmn & $90-116$ & 6.18 & 74.87 & abcdefghijk & $60-92$ & 12.70 & 31.07 & efghijklmno & $16-44$ & 24.07 \\
\hline 28 & 82.13 & efghij & $68-96$ & 7.73 & 98 & klmnopq & $84-114$ & 7.47 & 75.8 & abcdefghij & $60-90$ & 9.58 & 32.33 & cdefghijklmn & $20-42$ & 19.84 \\
\hline 29 & 80.6 & fghijk & $70-98$ & 7.26 & 94.6 & opqr & $80-112$ & 6.92 & 82.4 & $\mathrm{a}$ & 64-104 & 10.99 & 36.27 & bcdefg & $24-48$ & 18.24 \\
\hline 30 & 90.33 & $\mathrm{ab}$ & $74-110$ & 9.47 & 113.9 & $\mathrm{a}$ & $100-132$ & 8.16 & 80.93 & $a b c$ & $64-96$ & 8.87 & 31.87 & defghijklmno & $16-44$ & 19.36 \\
\hline 31 & 84.87 & bcdefgh & 70-104 & 9.11 & 104.1 & cdefghijk & $84-120$ & 8.54 & 70.8 & fghijklmn & $60-92$ & 12.40 & 33.67 & bcdefghijklm & $18-44$ & 19.80 \\
\hline 32 & 86.4 & abcdef & 66-114 & 11.60 & 102.7 & defghijklm & 90-116 & 7.00 & 74.73 & abcdefghijk & 56-92 & 12.22 & 35.87 & bcdefgh & $22-52$ & 18.34 \\
\hline 33 & 85.13 & bcdefgh & $70-116$ & 11.91 & 105.5 & bcdefghij & $84-142$ & 12.23 & 81.6 & $a b$ & 64-112 & 15.22 & 35.27 & bcdefghij & $24-48$ & 18.33 \\
\hline
\end{tabular}


Table A2. Cont.

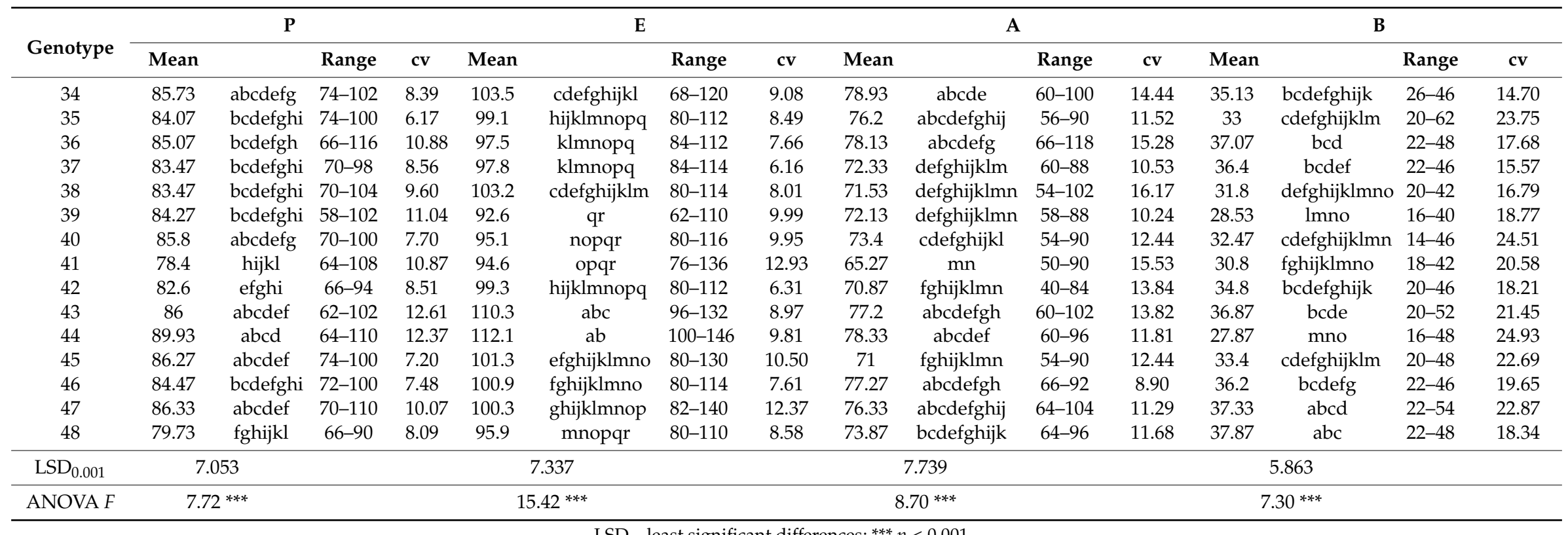

LSD—least significant differences; ${ }^{* * *} p<0.001$. 
Table A3. Mahalanobis distances between studied Abies genotypes (G).

\begin{tabular}{|c|c|c|c|c|c|c|c|c|c|c|c|c|c|c|c|c|c|c|c|c|c|c|c|}
\hline Genotype & 1 & 2 & 3 & 4 & 5 & 6 & 7 & 8 & 9 & 10 & 11 & 12 & 13 & 14 & 15 & 16 & 17 & 18 & 19 & 20 & 21 & 22 & 23 \\
\hline 2 & 1.63 & & & & & & & & & & & & & & & & & & & & & & \\
\hline 3 & 2.73 & 1.91 & & & & & & & & & & & & & & & & & & & & & \\
\hline 4 & 2.35 & 1.65 & 2.35 & & & & & & & & & & & & & & & & & & & & \\
\hline 5 & 2.77 & 1.97 & 0.94 & 2.01 & & & & & & & & & & & & & & & & & & & \\
\hline 6 & 1.33 & 0.72 & 1.64 & 1.71 & 1.65 & & & & & & & & & & & & & & & & & & \\
\hline 7 & 1.97 & 1.68 & 2.40 & 1.98 & 2.13 & 1.58 & & & & & & & & & & & & & & & & & \\
\hline 8 & 1.48 & 1.53 & 1.54 & 2.05 & 1.48 & 0.91 & 1.69 & & & & & & & & & & & & & & & & \\
\hline 9 & 2.43 & 1.66 & 1.08 & 1.99 & 0.76 & 1.30 & 2.06 & 1.40 & & & & & & & & & & & & & & & \\
\hline 10 & 2.86 & 1.53 & 1.67 & 1.82 & 1.32 & 1.73 & 1.98 & 2.03 & 1.44 & & & & & & & & & & & & & & \\
\hline 11 & 2.90 & 2.26 & 1.19 & 2.42 & 1.29 & 1.99 & 2.79 & 1.86 & 1.49 & 2.08 & & & & & & & & & & & & & \\
\hline 12 & 2.99 & 2.35 & 1.34 & 2.48 & 1.03 & 2.02 & 2.40 & 1.66 & 1.41 & 1.68 & 2.10 & & & & & & & & & & & & \\
\hline 13 & 4.11 & 3.89 & 3.68 & 3.53 & 3.15 & 3.65 & 3.56 & 3.14 & 3.66 & 3.36 & 3.87 & 2.71 & & & & & & & & & & & \\
\hline 14 & 2.11 & 1.30 & 2.73 & 1.69 & 2.56 & 1.75 & 1.50 & 2.25 & 2.47 & 1.84 & 2.85 & 3.01 & 3.99 & & & & & & & & & & \\
\hline 15 & 2.62 & 1.94 & 2.64 & 1.91 & 2.10 & 2.05 & 1.56 & 2.12 & 2.25 & 1.45 & 2.88 & 2.22 & 2.80 & 1.56 & & & & & & & & & \\
\hline 16 & 1.82 & 1.13 & 2.29 & 1.68 & 2.10 & 1.36 & 0.95 & 1.68 & 2.04 & 1.54 & 2.65 & 2.36 & 3.51 & 0.84 & 1.16 & & & & & & & & \\
\hline 17 & 2.67 & 1.73 & 2.31 & 1.66 & 2.24 & 2.00 & 2.37 & 2.42 & 2.24 & 1.90 & 1.92 & 3.03 & 4.31 & 1.53 & 2.36 & 1.91 & & & & & & & \\
\hline 18 & 4.00 & 3.22 & 3.53 & 3.06 & 3.20 & 3.46 & 2.40 & 3.49 & 3.53 & 2.48 & 3.89 & 3.25 & 3.65 & 2.46 & 1.92 & 2.27 & 3.16 & & & & & & \\
\hline 19 & 3.21 & 1.98 & 1.83 & 2.09 & 1.41 & 2.07 & 2.16 & 2.21 & 1.71 & 0.76 & 2.41 & 1.43 & 2.94 & 2.32 & 1.60 & 1.90 & 2.49 & 2.45 & & & & & \\
\hline 20 & 1.72 & 1.14 & 2.78 & 1.82 & 2.50 & 1.40 & 1.50 & 2.02 & 2.19 & 1.95 & 2.93 & 2.91 & 3.98 & 1.04 & 1.66 & 1.10 & 2.05 & 3.09 & 2.39 & & & & \\
\hline 21 & 2.02 & 1.16 & 2.36 & 1.38 & 2.14 & 1.34 & 1.63 & 1.98 & 1.90 & 1.84 & 2.30 & 2.85 & 4.12 & 1.17 & 2.04 & 1.43 & 1.27 & 3.19 & 2.32 & 1.11 & & & \\
\hline 22 & 2.82 & 1.85 & 1.35 & 2.15 & 1.25 & 1.77 & 2.07 & 1.64 & 1.73 & 1.32 & 1.82 & 1.40 & 2.75 & 2.29 & 1.91 & 1.86 & 2.24 & 2.72 & 1.19 & 2.50 & 2.23 & & \\
\hline 23 & 1.97 & 1.46 & 1.66 & 1.73 & 1.23 & 1.19 & 1.35 & 0.99 & 1.32 & 1.31 & 2.06 & 1.35 & 2.78 & 1.85 & 1.21 & 1.18 & 2.23 & 2.69 & 1.48 & 1.71 & 1.84 & 1.35 & \\
\hline 24 & 3.07 & 1.92 & 1.97 & 1.90 & 1.44 & 2.02 & 1.87 & 2.16 & 1.71 & 0.68 & 2.46 & 1.57 & 2.98 & 2.04 & 1.22 & 1.62 & 2.34 & 2.13 & 0.50 & 2.15 & 2.13 & 1.38 & 1.30 \\
\hline 25 & 2.04 & 1.09 & 1.78 & 1.47 & 1.35 & 1.10 & 1.49 & 1.43 & 1.27 & 1.00 & 1.88 & 1.91 & 3.34 & 1.37 & 1.26 & 1.09 & 1.57 & 2.76 & 1.52 & 1.25 & 1.19 & 1.55 & 0.88 \\
\hline 26 & 1.91 & 1.64 & 2.94 & 2.11 & 2.60 & 1.75 & 1.13 & 2.09 & 2.45 & 2.19 & 3.02 & 3.04 & 3.86 & 1.07 & 1.57 & 1.09 & 2.16 & 2.74 & 2.56 & 0.85 & 1.34 & 2.51 & 1.77 \\
\hline 27 & 1.88 & 0.81 & 1.58 & 1.57 & 1.45 & 0.85 & 1.49 & 1.24 & 1.40 & 1.25 & 1.72 & 2.01 & 3.43 & 1.34 & 1.64 & 1.11 & 1.45 & 2.91 & 1.68 & 1.39 & 1.10 & 1.29 & 1.08 \\
\hline 28 & 1.98 & 1.08 & 1.49 & 1.74 & 1.42 & 0.99 & 1.18 & 1.16 & 1.45 & 1.29 & 2.08 & 1.64 & 3.20 & 1.61 & 1.59 & 1.02 & 2.04 & 2.64 & 1.43 & 1.67 & 1.58 & 1.09 & 0.89 \\
\hline 29 & 1.87 & 2.00 & 2.07 & 2.52 & 2.19 & 1.61 & 1.58 & 1.23 & 2.22 & 2.53 & 2.74 & 2.05 & 3.26 & 2.50 & 2.44 & 1.84 & 3.03 & 3.28 & 2.49 & 2.46 & 2.50 & 1.90 & 1.60 \\
\hline 30 & 1.80 & 1.31 & 2.96 & 1.95 & 2.93 & 1.70 & 2.02 & 2.41 & 2.62 & 2.45 & 2.95 & 3.49 & 4.69 & 1.07 & 2.44 & 1.57 & 1.64 & 3.50 & 2.99 & 1.13 & 1.06 & 2.86 & 2.37 \\
\hline 31 & 2.95 & 2.07 & 2.92 & 2.02 & 2.59 & 2.43 & 1.74 & 2.69 & 2.74 & 1.70 & 3.12 & 2.89 & 3.63 & 1.14 & 1.14 & 1.22 & 2.00 & 1.41 & 2.02 & 1.87 & 2.00 & 2.24 & 1.94 \\
\hline 32 & 1.70 & 1.18 & 2.27 & 1.63 & 1.91 & 1.18 & 0.86 & 1.45 & 1.79 & 1.56 & 2.53 & 2.23 & 3.32 & 1.13 & 1.10 & 0.61 & 2.02 & 2.57 & 1.88 & 0.89 & 1.29 & 1.88 & 0.95 \\
\hline 33 & 1.44 & 1.30 & 2.50 & 1.67 & 2.50 & 1.41 & 1.21 & 1.74 & 2.36 & 2.24 & 2.82 & 2.79 & 3.91 & 1.17 & 1.99 & 0.95 & 2.02 & 2.86 & 2.56 & 1.45 & 1.49 & 2.28 & 1.72 \\
\hline 34 & 1.08 & 0.98 & 2.11 & 1.61 & 2.01 & 0.63 & 1.29 & 1.15 & 1.66 & 2.04 & 2.42 & 2.36 & 3.76 & 1.61 & 2.03 & 1.25 & 2.14 & 3.40 & 2.35 & 1.19 & 1.26 & 2.14 & 1.35 \\
\hline 35 & 1.92 & 1.17 & 1.79 & 1.56 & 1.59 & 1.13 & 0.80 & 1.30 & 1.61 & 1.38 & 2.23 & 1.90 & 3.26 & 1.32 & 1.37 & 0.72 & 1.91 & 2.40 & 1.59 & 1.46 & 1.38 & 1.37 & 0.90 \\
\hline 36 & 1.91 & 1.77 & 2.36 & 2.00 & 2.08 & 1.59 & 0.66 & 1.46 & 2.14 & 2.01 & 2.80 & 2.15 & 3.00 & 1.70 & 1.41 & 1.02 & 2.57 & 2.39 & 2.06 & 1.72 & 1.94 & 1.84 & 1.12 \\
\hline 37 & 2.04 & 1.51 & 2.07 & 1.71 & 1.60 & 1.37 & 0.98 & 1.34 & 1.67 & 1.41 & 2.46 & 1.73 & 2.81 & 1.60 & 0.92 & 0.93 & 2.30 & 2.38 & 1.51 & 1.48 & 1.73 & 1.53 & 0.56 \\
\hline 38 & 1.92 & 0.85 & 1.62 & 1.44 & 1.39 & 0.88 & 1.52 & 1.43 & 1.06 & 1.13 & 1.86 & 1.97 & 3.73 & 1.45 & 1.66 & 1.18 & 1.57 & 3.02 & 1.68 & 1.26 & 1.07 & 1.73 & 1.11 \\
\hline 39 & 2.75 & 1.74 & 1.54 & 1.75 & 1.07 & 1.56 & 1.72 & 1.72 & 1.23 & 1.28 & 1.98 & 1.57 & 3.19 & 2.22 & 1.93 & 1.84 & 2.23 & 2.93 & 1.18 & 2.13 & 1.73 & 1.24 & 1.37 \\
\hline 40 & 2.42 & 1.79 & 2.00 & 1.52 & 1.45 & 1.63 & 1.02 & 1.62 & 1.63 & 1.49 & 2.26 & 1.88 & 3.01 & 1.74 & 1.33 & 1.30 & 2.08 & 2.34 & 1.57 & 1.80 & 1.56 & 1.54 & 1.06 \\
\hline
\end{tabular}


Table A3. Cont.

\begin{tabular}{|c|c|c|c|c|c|c|c|c|c|c|c|c|c|c|c|c|c|c|c|c|c|c|c|c|}
\hline Genotype & 1 & 2 & 3 & 4 & 5 & 6 & 7 & 8 & 9 & 10 & 11 & 12 & 13 & 14 & 15 & 16 & 17 & 18 & 19 & 20 & 21 & 22 & 23 & \\
\hline 41 & 2.95 & 1.79 & 1.52 & 1.72 & 1.03 & 1.82 & 1.98 & 1.94 & 1.34 & 0.58 & 2.01 & 1.30 & 3.06 & 2.13 & 1.53 & 1.72 & 2.12 & 2.49 & 0.58 & 2.24 & 2.04 & 1.17 & 1.22 & \\
\hline 42 & 2.06 & 1.29 & 1.83 & 1.50 & 1.38 & 1.23 & 1.11 & 1.34 & 1.41 & 1.08 & 2.18 & 1.68 & 3.04 & 1.44 & 0.95 & 0.84 & 1.96 & 2.40 & 1.36 & 1.40 & 1.51 & 1.44 & 0.52 & \\
\hline 43 & 1.12 & 1.09 & 2.66 & 1.73 & 2.53 & 1.16 & 1.92 & 1.72 & 2.21 & 2.27 & 2.69 & 2.93 & 3.96 & 1.42 & 2.10 & 1.45 & 1.98 & 3.63 & 2.72 & 0.95 & 1.30 & 2.55 & 1.79 & \\
\hline 44 & 2.40 & 1.49 & 2.87 & 2.06 & 2.83 & 1.85 & 2.67 & 2.58 & 2.56 & 2.40 & 2.66 & 3.49 & 4.62 & 1.76 & 2.78 & 2.21 & 1.58 & 3.99 & 2.90 & 1.66 & 1.21 & 2.72 & 2.61 & \\
\hline 45 & 2.10 & 1.22 & 2.08 & 1.38 & 1.55 & 1.21 & 1.35 & 1.59 & 1.41 & 1.20 & 2.23 & 2.06 & 3.32 & 1.40 & 1.22 & 1.14 & 1.83 & 2.78 & 1.57 & 1.07 & 1.11 & 1.77 & 1.02 & \\
\hline 46 & 1.40 & 1.10 & 2.05 & 1.70 & 1.83 & 0.86 & 1.00 & 1.00 & 1.73 & 1.75 & 2.41 & 2.04 & 3.16 & 1.47 & 1.48 & 0.88 & 2.20 & 2.88 & 1.96 & 1.23 & 1.48 & 1.68 & 0.87 & \\
\hline 47 & 2.29 & 2.13 & 2.83 & 1.92 & 2.45 & 2.12 & 1.03 & 2.06 & 2.58 & 2.20 & 3.01 & 2.68 & 3.20 & 1.47 & 1.26 & 1.13 & 2.34 & 1.98 & 2.38 & 1.82 & 1.97 & 2.25 & 1.56 & \\
\hline \multirow[t]{3}{*}{48} & 1.92 & 1.75 & 1.92 & 1.95 & 1.63 & 1.43 & 1.34 & 0.98 & 1.81 & 1.81 & 2.35 & 1.55 & 2.53 & 2.02 & 1.43 & 1.31 & 2.53 & 2.69 & 1.83 & 1.99 & 2.14 & 1.43 & 0.64 & \\
\hline & 1 & 2 & 3 & 4 & 5 & 6 & 7 & 8 & 9 & 10 & 11 & 12 & 13 & 14 & 15 & 16 & 17 & 18 & 19 & 20 & 21 & 22 & 23 & \\
\hline & 24 & 25 & 26 & 27 & 28 & 29 & 30 & 31 & 32 & 33 & 34 & 35 & 36 & 37 & 38 & 39 & 40 & 41 & 42 & 43 & 44 & 45 & 46 & 47 \\
\hline 25 & 1.31 & & & & & & & & & & & & & & & & & & & & & & & \\
\hline 26 & 2.25 & 1.46 & & & & & & & & & & & & & & & & & & & & & & \\
\hline 27 & 1.60 & 0.67 & 1.54 & & & & & & & & & & & & & & & & & & & & & \\
\hline 28 & 1.38 & 1.08 & 1.72 & 0.79 & & & & & & & & & & & & & & & & & & & & \\
\hline 29 & 2.46 & 2.18 & 2.36 & 1.88 & 1.30 & & & & & & & & & & & & & & & & & & & \\
\hline 30 & 2.79 & 1.81 & 1.46 & 1.66 & 2.08 & 2.79 & & & & & & & & & & & & & & & & & & \\
\hline 31 & 1.65 & 1.69 & 1.69 & 1.86 & 1.89 & 2.81 & 2.19 & & & & & & & & & & & & & & & & & \\
\hline 32 & 1.60 & 0.85 & 0.87 & 1.03 & 1.05 & 1.83 & 1.67 & 1.55 & & & & & & & & & & & & & & & & \\
\hline 33 & 2.35 & 1.69 & 1.45 & 1.47 & 1.37 & 1.67 & 1.38 & 1.88 & 1.22 & & & & & & & & & & & & & & & \\
\hline 34 & 2.21 & 1.31 & 1.47 & 1.18 & 1.20 & 1.58 & 1.53 & 2.37 & 1.02 & 1.08 & & & & & & & & & & & & & & \\
\hline 35 & 1.40 & 1.00 & 1.39 & 0.86 & 0.47 & 1.42 & 1.89 & 1.58 & 0.76 & 1.11 & 1.11 & & & & & & & & & & & & & \\
\hline 36 & 1.82 & 1.56 & 1.42 & 1.52 & 1.08 & 1.23 & 2.30 & 1.83 & 0.94 & 1.28 & 1.37 & 0.81 & & & & & & & & & & & & \\
\hline 37 & 1.24 & 0.97 & 1.41 & 1.18 & 0.90 & 1.63 & 2.25 & 1.65 & 0.64 & 1.55 & 1.34 & 0.72 & 0.76 & & & & & & & & & & & \\
\hline 38 & 1.51 & 0.54 & 1.61 & 0.76 & 1.08 & 2.14 & 1.65 & 1.94 & 1.02 & 1.59 & 1.10 & 1.05 & 1.70 & 1.23 & & & & & & & & & & \\
\hline 39 & 1.22 & 1.35 & 2.22 & 1.32 & 1.13 & 2.05 & 2.62 & 2.33 & 1.63 & 2.21 & 1.76 & 1.25 & 1.76 & 1.38 & 1.35 & & & & & & & & & \\
\hline 40 & 1.28 & 1.16 & 1.60 & 1.30 & 1.10 & 1.86 & 2.35 & 1.72 & 1.07 & 1.71 & 1.55 & 0.83 & 1.07 & 0.82 & 1.34 & 1.04 & & & & & & & & \\
\hline 41 & 0.55 & 1.21 & 2.41 & 1.43 & 1.28 & 2.37 & 2.75 & 1.91 & 1.69 & 2.31 & 2.09 & 1.38 & 1.94 & 1.36 & 1.32 & 1.05 & 1.31 & & & & & & & \\
\hline 42 & 1.08 & 0.62 & 1.45 & 0.94 & 0.83 & 1.81 & 2.06 & 1.52 & 0.65 & 1.52 & 1.29 & 0.66 & 1.06 & 0.44 & 0.88 & 1.27 & 0.82 & 1.10 & & & & & & \\
\hline 43 & 2.56 & 1.44 & 1.46 & 1.40 & 1.80 & 2.36 & 1.11 & 2.36 & 1.30 & 1.39 & 1.02 & 1.69 & 1.95 & 1.78 & 1.39 & 2.38 & 2.12 & 2.48 & 1.67 & & & & & \\
\hline 44 & 2.85 & 1.91 & 2.12 & 1.68 & 2.30 & 3.20 & 1.24 & 2.70 & 2.15 & 2.21 & 1.97 & 2.28 & 2.85 & 2.59 & 1.82 & 2.50 & 2.61 & 2.72 & 2.37 & 1.50 & & & & \\
\hline 45 & 1.32 & 0.52 & 1.30 & 0.96 & 1.19 & 2.22 & 1.82 & 1.74 & 0.73 & 1.70 & 1.24 & 1.03 & 1.47 & 0.89 & 0.74 & 1.25 & 1.01 & 1.34 & 0.69 & 1.46 & 1.95 & & & \\
\hline 46 & 1.80 & 1.09 & 1.27 & 0.97 & 0.80 & 1.31 & 1.82 & 1.97 & 0.63 & 1.12 & 0.75 & 0.71 & 0.81 & 0.75 & 1.17 & 1.58 & 1.21 & 1.79 & 0.86 & 1.28 & 2.21 & 1.06 & & \\
\hline 47 & 2.01 & 1.71 & 1.35 & 1.82 & 1.67 & 2.05 & 2.25 & 1.34 & 1.19 & 1.42 & 1.85 & 1.25 & 0.95 & 1.20 & 1.95 & 2.20 & 1.24 & 2.16 & 1.33 & 2.11 & 2.92 & 1.65 & 1.42 & \\
\hline \multirow[t]{2}{*}{48} & 1.69 & 1.39 & 1.89 & 1.38 & 1.01 & 1.20 & 2.57 & 2.10 & 1.18 & 1.64 & 1.48 & 1.00 & 0.84 & 0.75 & 1.61 & 1.66 & 1.21 & 1.65 & 0.96 & 1.97 & 2.89 & 1.48 & 0.87 & 1.42 \\
\hline & 24 & 25 & 26 & 27 & 28 & 29 & 30 & 31 & 32 & 33 & 34 & 35 & 36 & 37 & 38 & 39 & 40 & 41 & 42 & 43 & 44 & 45 & 46 & 47 \\
\hline
\end{tabular}




\section{References}

1. Petit, R.J.; Hampe, A. Some evolutionary consequences of being a tree. Annu. Rev. Ecol. Evol. Syst. 2006, 37, 187-214. [CrossRef]

2. García, D.; Zamora, R.; Gómez, J.M.; Hódar, J.A. Annual variability in reproduction of Juniperus communis L. in a Mediterranean Mountain: Relationship to seed predation and weather. Écoscience 2002, 9, 251-255. [CrossRef]

3. Korpel', S.; Paule, L.; Laffers, A. Genetics and breeding of the silver fir (Abies alba Mill.). Ann. For. 1982, 9, 151-184.

4. Vitasse, Y.; Bottero, A.; Rebetez, M.; Conedera, M.; Augustin, S.; Brang, P.; Tinner, W. What is the potential of silver fir to thrive under warmer and drier climate? Eur. J. For. Res. 2019, 138, 547-560. [CrossRef]

5. Barzdajn, W. A strategy for restitution of silver fir (Abies alba Mill.) in the Sudety Mountains. Sylwan 2000, 144, 63-77.

6. Tinner, W.; Ammann, B. Long-term responses of mountain ecosystems to environmental changes: Resilience, adjustment, and vulnerability. In Global Change and Mountain Regions; Huber, U.M., Bugmann, H., Reasoner, M., Eds.; Springer: Dordrecht, The Netherlands, 2005; pp. 133-143.

7. Ellenberg, H. Vegetation Ecology of Central Europe, 4th ed.; Cambridge University Press: Cambridge, UK, 2009; pp. 3-557.

8. Henne, P.D.; Elkin, C.M.; Reineking, B.; Bugmann, H.; Tinner, W. Did soil development limit spruce (Picea abies) expansion in the Central Alps during the Holocene? Testing a palaeobotanical hypothesis with a dynamic landscape model. J. Biogeogr. 2011, 38, 933-949. [CrossRef]

9. Dyderski, M.K.; Paź, S.; Frelich, L.E.; Jagodziński, A.M. How much does climate change threaten european forest tree species distributions? Glob. Chang. Biol. 2018, 24, 1150-1163. [CrossRef]

10. CILP Raport o Stanie Lasów w Polsce. 2017. Available online: https://www.lasy.gov.pl/pl/informacje/ publikacje/informacje-statystyczne-i-raporty/raport-o-stanie-lasow/raport-za-2017-2.pdf/view (accessed on 6 August 2020).

11. Dobrowolska, D. Ecology and silviculture of silver fir (Abies alba Mill.): A review. J. For. Res. 2017, 22, 326-335. [CrossRef]

12. McCartan, S.; Jinks, R. Upgrading Seed Lots of European Silver Fir (Abies alba Mill.) Using Imbibition-DryingSeparation. Tree Plant. Notes 2015, 58, 21-27.

13. Eisenhut, G. Untersuchungen über die Morphologie und ökologie der Pollenkörner Heimischer und Fremdländischer Waldbäume [Studies on the Morphology and Ecology of Native Pollen Grains of Forest Trees]; Forstwissenschaftliche Forschungen; Paul Parey Vlg.: Berlin, Germany, 1961; pp. 1-68.

14. Oddou-Muratorio, S.; Bontemps, A.; Klein, E.K.; Chybicki, I.; Vendramin, G.G.; Suyama, Y. Comparison of Direct and Indirect Genetic Methods for Estimating Seed and Pollen Dispersal in Fagus Sylvatica and Fagus Crenata. For. Ecol. Manag. 2010, 259, 2151-2159. [CrossRef]

15. Poska, A.; Pidek, I.A. Pollen dispersal and deposition characteristics of Abies alba, Fagus sylvatica and Pinus sylvestris, Roztocze Region (SE Poland). Veg. Hist. Archaeobot. 2010, 19, 91-101. [CrossRef]

16. Feurdean, A.; Willis, K.J. Long-term variability of Abies alba in NW Romania:implications for its conservation management. Divers. Distrib. 2008, 14, 1004-1017. [CrossRef]

17. Koelewijn, H.P.; Koski, V.; Savolainen, O. Magnitude and timing of inbreeding depression in scots pine (Pinus sylvestris L.). Evolution 1999, 53, 758-768. [CrossRef] [PubMed]

18. Ting, W.S. The saccate pollen grains of Pinaceae mainly of California. Grana 1965, 6, 270-289. [CrossRef]

19. Gudeski, A. Morphological characteristics of the pollen grains of Abies alba from populations in Macedonia and of A. cephalonica from Parnis in Greece. Godisen Zbornik na Zemjodelsko-Smarskiot 1974, 26, 133-147.

20. Bagnell, C.R. Species distinction among pollen grains of Abies, Picea, and Pinus in the rocky mountain area (a scanning electron microscope study). Rev. Palaeobot. Palynol. 1975, 19, 203-220. [CrossRef]

21. Dobrinov, I.; Gagov, V. Study on the pollen of the Silver Fir (Abies alba Mill.) in Bulgaria. High. Inst. For. Res. Work. Ser. For. 1975, 20, 9-16.

22. Halbritter, H. PalDat-A Palynological Database. 2015. Available online: https://www.paldat.org/pub/ Abies_cephalonica/300056 (accessed on 15 May 2020).

23. Halbritter, H. PalDat-A Palynological Database. 2016. Available online: https://www.paldat.org/pub/ Abies_concolor/300647 (accessed on 15 May 2020). 
24. Halbritter, H. PalDat-A Palynological Database. 2016. Available online: https://www.paldat.org/pub/ Abies_nordmanniana/300648 (accessed on 15 May 2020).

25. Khan, R.; Ul Abidin, S.Z.; Ahmad, M.; Zafar, M.; Liu, J.; Amina, H. Palyno-morphological characteristics of gymnosperm flora of Pakistan and its taxonomic implications with LM and SEM methods. Microsc. Res. Tech. 2017, 81, 74-87. [CrossRef]

26. Faegri, K.; Iversen, J. Textbook of Pollen Nalysis; John Wiley \& Sons: Chichester, UK, 1978.

27. Dumolin, S.; Demesure, B.; Petit, R.J. Inheritance of chloroplast and mitochondrial genomes in pedunculate oak investigated with an efficient PCR method. Theor. Appl. Genet. 1995, 91, 1253-1256. [CrossRef]

28. Cremer, E.; Liepelt, S.; Sebastiani, F.; Buonamici, A.; Michalczyk, I.M.; Ziegenhagen, B.; Vendramin, G.G. Identification and characterization of nuclear microsatellite loci in Abies alba Mill. Mol. Ecol. Notes 2006, 6, 374-376. [CrossRef]

29. Dering, M.; Sękiewicz, K.; Boratyńska, K.; Litkowiec, M.; Iszkuło, G.; Romo, A.; Boratyński, A. Genetic diversity and inter-specific relations of Western Mediterranean relic Abies taxa as compared to the Iberian A. alba. Flora 2014, 209, 367-374. [CrossRef]

30. Euforgen. Distribution map of silver fir (Abies alba). 2011. Available online: http://www.euforgen.org (accessed on 20 July 2020).

31. Wrońska-Pilarek, D.; Jagodziński, A.M.; Bocianowski, J.; Janyszek, M. The optimal sample size in pollen morphological studies using the example of Rosa canina L.-Rosaceae. Palynology 2015, 39, 56-75. [CrossRef]

32. Erdtman, G. The acetolysis method. A revised description. Svensk Bot. Tidskr. 1960, 54, 561-564.

33. Punt, W.; Hoen, P.P.; Blackmore, S.; Nilsson, S.; Le Thomas, A. Glossary of pollen and spore terminology. Rev. Palaeobot. Palynol. 2007, 143,1-81. [CrossRef]

34. Halbritter, H.; Hess, U.S.; Grímsson, F.; Weber, M.; Zetter, R.; Hesse, M.; Buchner, R.; Svojtka, M.; Frosch-Radivo, A. Illustrated Pollen Terminology, 2nd ed.; Springer: Vienna, Austria, 2018; pp. 3-415.

35. Shapiro, S.S.; Wilk, M.B. An analysis of variance test for normality (complete samples). Biometrika 1965, 52, 591-611. [CrossRef]

36. Rencher, A.C. Interpretation of canonical discriminant functions, canonical variates, and principal components. Am. Stat. 1992, 46, 217-225.

37. Seidler-Łożykowska, K.; Bocianowski, J.; Król, D. The evaluation of the variability of morphological and chemical traits of the selected lemon balm (Melissa officinalis L.) genotypes. Ind. Crops Prod. 2013, 49, 515-520. [CrossRef]

38. Lahuta, L.B.; Ciak, M.; Rybiński, W.; Bocianowski, J.; Börner, A. Diversity of the composition and content of soluble carbohydrates in seeds of the genus Vicia (Leguminosae). Genet. Resour. Crop Evol. 2018, 65, 541-554. [CrossRef]

39. Wrońska-Pilarek, D.; Szkudlarz, P.; Bocianowski, J. Systematic importance of morphological features of pollen grains of species from Erica (Ericaceae) genus. PLoS ONE 2018, 13, e0204557. [CrossRef]

40. Bocianowski, J.; Majchrzak, L. Analysis of effects of cover crop and tillage method combinations on the phenotypic traits of spring wheat (Triticum aestivum L.) using multivariate methods. Appl. Ecol. Environ. Res. 2019, 17, 15267-15276. [CrossRef]

41. Mahalanobis, P.C. On the generalized distance in statistics. Proc. Natl. Inst. Sci. India 1936, 12, 49-55.

42. Seidler-Łożykowska, K.; Bocianowski, J. Evaluation of variability of morphological traits of selected caraway (Carum carvi L.) genotypes. Ind. Crops Prod. 2012, 35, 140-145. [CrossRef]

43. Camussi, A.; Ottaviano, E.; Caliński, T.; Kaczmarek, Z. Genetic distances based on quantitative traits. Genetics 1985, 111, 945-962.

44. Erdtman, G. Pollen Morphology and Plant Taxonomy-Angiosperms: An Introduction to Palynology, 1st ed.; Almquist and Wiksell: Stockholm, Sweden, 1952.

45. Erdtman, G. Pollen and Spore Morphology and Plant Taxonomy-Gymnospermae, Pteridophyta, Bryophyta; Almquist and Wiksell: Stockholm, Sweden; New York, NY, USA, 1957.

46. Wrońska-Pilarek, D.; Bocianowski, J.; Jagodziński, A.M. Comparison of pollen grain morphological features of selected species of the genus Crataegus L. (Rosaceae) and their spontaneous, interspecific hybrids. Bot. J. Linn. Soc. 2013, 172, 555-571. 
47. Wrońska-Pilarek, D.; Danielewicz, W.; Bocianowski, J.; Maliński, T.; Janyszek, M. Comparative pollen morphological analysis and its systematic implications on three european oak (Quercus L., Fagaceae) species and their spontaneous hybrids. PLOS ONE 2016, 11, e0161762. [CrossRef]

48. Lechowicz, K.; Wrońska-Pilarek, D.; Bocianowski, J.; Maliński, T. Pollen morphology of Polish species from the genus Rubus L. (Rosaceae) and its systematic importance. PLoS ONE 2020, 15, e0221607.

Publisher's Note: MDPI stays neutral with regard to jurisdictional claims in published maps and institutional affiliations.

(C) 2020 by the authors. Licensee MDPI, Basel, Switzerland. This article is an open access article distributed under the terms and conditions of the Creative Commons Attribution (CC BY) license (http://creativecommons.org/licenses/by/4.0/). 